Historic, Archive Document

Do not assume content reflects current scientific knowledge, policies, or practices. 


$$
\text { - }
$$




\section{WM. E. ATTWOOD}

COMPANY, INC.

Seeds - Bulbs - Plants

\section{COOK AVENUE}

LAKEWOOD, OHIO

BOulevard 3566
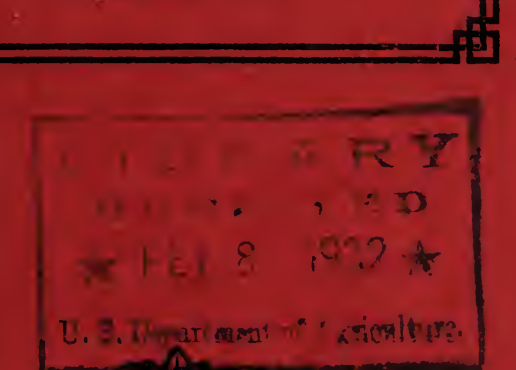

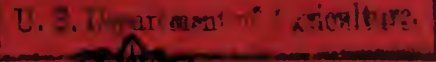

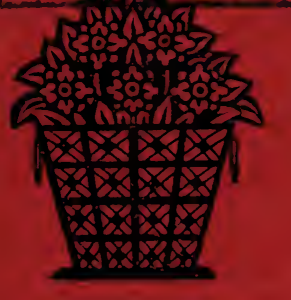

Offerings for 1932 


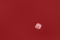




\section{Novelties and Specialties for 1932}

\section{WM. E. ATTWOOD CO., Inc.}

1202 Cook Avenue, LAKEWOOD, OHIO

DAHLIA UNWIN'S DWARF HYBRIDS. These bedding Hybrids are the outcome of 10 years' hybridisation and selection, and must not be confused with the ordinary single Coltness Hybrids. The original parents were Coltness Gem and, on the other side, the finest varieties of the Charm or Miniature Paeony Flowered Type. Messrs. UNWIN'S object has been the combination of the best qualities of both types, the wonderful dwarf habit and freedom of Coltness Gem with the dainty semi-double form and the wide range of exquisite colorings of the Charms. This object has been achieved-the hybrids are early, blooming in four months from the time of sowing, and they embrace a wide and most charming color range. In the main they are semi-double, require no stakes, may be planted 18 to 20 inches apart, and average between 18 and 24 inches in height. Their freedom of flowering is remarkable. Given exactly the same treatment, they are much easier to raise than Asters or Stocks. Sown in March they commence blooming at the end of June or beginning of July and continue until the first severe frost. Their popularity is assured; all who have seen them have been very impressed. PER PACKET $\$ 1.00$

URSINIA ANETHOIDES NEW HYBRIDS. We predict a wonderful future for the Jewels of the Veldt (Ursinias). The plants make bushes $2 \mathrm{ft}$. through and carry a hundred or more fully expanded flowers at one time. The foliage is light and feathery and the flowers are carried singly well above the leaves, on thin wiry stems of sufficient length for decorative or vase work. The blooms last splendidly in a cut state. The petals of all are of a delightful rich orange tone, but it is the central coloring surrounding the disc that shows the wonderful variation. The width of the rings vary from $1 / 8$ to $3 / 4$ inch, and tone from ruby red to dark purple, spangled with the distinctive jewel-like dots. From seeds sown outdoors in April, plants commence to flower in June, and continue until September. Height 1 to $1 \frac{1}{2} \mathrm{ft}$. PER PACKET _._. $75 \mathrm{c}$

ASTER DOUBLE LILIPUT. A small flowered intensely double Aster, which is admirably suitable for pot culture. Of recent years it has become very popular for market work on accunt of the neat symmetrical form of the flowers; the plants are of ideal habit and are about one foot in height. 
At last yea:'s R. H. S. Autumn Show they created quite a sensation and again this year (1931) at Southport (England) attracted very considerable attention.

These Liliput Asters come p:actically 100\%, true to color and we feel that our customers should give them a place in their gardens. We offer them in the following colors: CRIMSON, DARK BLUE, PURE WHITE, ROSE, SCARLET, WHITE WITH ROSE CENTER, WHITE WITH BLUE CENTER. Price for above collection $\$ 2.00$

CHRYSANTHEMUM SEGETUM ELDORADO. AIthough not a Novelty, this very welcome addition to the annual Chrysanthemums has not hitherto been offered for sale generally. Its flowers are canary yellow, many shades deeper than the existing varieties, and their beauty is enhanced by a very da:k disc. A variety we recommend all our customers to grow. PER PACKET'_-__-_-_-_ 75 =

LINARIA CANON WANT. A hardy perennial pale pink Linaria. $2 \frac{1}{2}$ to $3 \mathrm{ft}$. in height, coming perfectly tzue from seed. PER PACKET

MECONOPSIS BAILEYII. This beautiful blue perennial Poppy grows 2-3 feet high, with broad, sea-green leaves, and large blooms of a glorius sky-blue color. It is hardy, and has obtained from the R. H. S. a First Class Certificate and an Award of Merit. Prefers a moist and half shaded position. PER PACKET $75 c$

FELICIA RERGERIANA. Tufted grass-like foliage, from which are thrown masses of small blue star-shaped flowers. A really pretty annual of unique beauty.

PER PACKET $\$ 1.00$

VENIDIUM FASTUOSUM. Immense golden yellow flowers, with brown band encircling dark disc. A wonderful annual. PER PACKET $75 c$

TAGETES "GUINEA GOLD". This is a distinct type of Tageies, of graceful pyramidal habit, growing $2 \frac{1}{2}$ to $3 \mathrm{ft}$. high, and producing 30 to 40 flowers to the plant, 2 to $2 \frac{1}{2}$ inches across of a brilliant shade of orange, flushed with gold. 'This variety produces no sing'-e flowers, but practicaliy 100\%; semi-double and double. "GUINEA GOLD" is recommended both for "under glass' culture (grown cool) as well as for outdoors. Seed limited.

PACKET $\$ 1.00 ; 1 / 8$ oz. $\$ 2.50$. 


\title{
Greenhouse Plants.
}

\author{
Wm. E. Attwood Co., Inc.
}

AGAPANTHUS UMBELLATUS. Strong 6 inch pots. $\$ 12.00$ per Gozen.

AMARYLLIS GIANT AMERICAN HYBRIDS. Flowers cf enormous size, with full, rounded, broad petals, 10 inches in diameier, are not unusual and 5 to 6 flowers to a stem, frequently two stems being pushed to the bulb. In color there are selfs and stripes, ranging from the purest white grcund color with rose or red markings to rich orangescarlet, cherry, crimson and maroon. Strong flowering bulbs which we can supply in mixture only. $\$ 12.00$ per dozen; $\$ 90.00$ per 100 .

BOUGAINVILLEA Crimson Lake. The flowers are like all other Bougainvilleas, perhaps a trifle larger, but in coloring none compare with it in richness and brilliancy. On first opening a brilliant crimson-lake, retaining this color for 3 or 4 weeks, after which they gradually pass to a crimson. 4 inch pots, $\$ 7.00$ per dozen.

CAMELLIA JAPONICA. We offer a nice lot of thrifty plants 12 to 15 inches high in 6 inch pots in soft double pink. $\$ 4.00$ each.

\section{CLERODENDRON Balfouri.}

3 inch pots $\$ 3.00$ per dozen; $\$ 20.00$ per 100 .

4 inch pots $\$ 6.00$ per dozen; $\$ 40.00$ per 100 .

CLIVIA (Imantophyllum) Miniata. A very select strain. 5 inch pots $\$ 2.50 ; 6$ inch pots $\$ 4.00$ each.

ADIANTUM GLORIOSUM (Glory Fern). This is the most beautiful of the Maidenhairs, and which has displaced Adiantum Farleyense; it is just as handsome and while Farleyense was a very difficult variety to grow, the Glory Fern is as easily hand ed as any of the ordinary Adaintums.

$21 / 4$ inch pots $\$ 5.00$ per dozen; $\$ 40.00$ per 100 .

3 inch pots 10.00 per dozen; 90.00 per 100 .

ASPLENIUM NIDUS A.VIS (Bird's Nest Fern). A splendid healthy, clean lot of plants. $3 \frac{1}{2}$ inch pots $\$ 1.50$ each; 5 inch pots $\$ 3.00$ each; Specimen plants in 7 inch pots, $\$ 4.50$ each.

PLATYCERIUM ALCICORNE MAJOR (Stag-Horn Fern). One of the prettiest and easiest growing varieties of the interesting Stag Horn Ferns, a splendid plant for the conservatory.

Strong 3 inch plants, $\$ 2.00$ each.

Strong 5 inch plants, $\$ 5.00$ each.

TRAINED BALL-SHAPED ENGLISH IVIES. These ball-shaped Ivies are meeting with considerable favor. We cfficr 6 inch pots, balls 10 to 12 inches in diameter at $\$ 3.00$ each.

OLEA FRAGRANS (Sweet Olive). An old favorite greenhouse shrub succeeding admirably as a house plant, producing small creamy white flowers of the most exquisite fragrance, continues to bloom almost the entire winter. 4 inch pots $\$ 1.50$ each. 


\section{General Collection of Ferns}

\section{$2 \frac{1}{1}$ in. pots}

\begin{tabular}{|c|c|c|}
\hline \multicolumn{2}{|c|}{ VARIETY } & PER 10 \\
\hline \multicolumn{3}{|c|}{ Adiantum Cuneatum } \\
\hline \multicolumn{3}{|c|}{ Adiantum Hybridum } \\
\hline \multicolumn{3}{|c|}{ Aspidium Tsussimense } \\
\hline \multicolumn{3}{|c|}{ Blechnum Braziliensis _ 20.00} \\
\hline \multicolumn{3}{|c|}{ Cyrtomium Rochfordianum Compactum } \\
\hline \multicolumn{3}{|c|}{ Lygodium Dichotomum } \\
\hline \multicolumn{3}{|c|}{ Pteris Adiantoides } \\
\hline & Alexandrea & 12.00 \\
\hline$"$ & Cretica Albo Lineata & -12.00 \\
\hline$"$ & Rivertoniana & -12.00 \\
\hline , & Victoriae & -12.00 \\
\hline$"$ & Wilsoni _..-- & -12.00 \\
\hline$"$ & Wimsetti & --12.00 \\
\hline & Wimsetti Multiceps & \\
\hline
\end{tabular}

Sitolobium Cicutarium _-_ 12.00

\section{PANDANUS VEITCHI}

$\mathrm{EACH}$

Good 6 inch pots

7 inch pots _- 5.00

7 inch tubs _- 6.50

8 inch tubs 10.00

PLUMBAGO

PER DOZEN

Capensis Blue 3 inch pots ___ $\$ 3.00$

Capensis Alba 3 inch pots

Coccinea Superba 3 inch pots

\section{STIGMAPHYLLON CILIATUM}

(Brazilian Golden, or Orchid Vine)

One of the prettiest tender climbers in cultivation, with large yellow, orchid-like flowers, produced very freely during the summer months. It is especially adapted for training over the pillars or on the wall of a conservatory, but will do equally as well in the open air. $\$ 1.00$ each

\section{STRELITZIA}

(Bird of Paradise Flower)

REGINA. A serviceable conservatory plant, with dark green leathery foliage, and producing interesting curiously shaped orange and purplish blue flowers that always attract attention. 5 inch pots

WM. E. ATTWOOD CO., Inc. 1202 Cook Ave. 


\section{William E. Attwood Co. INCORPORATED}

Seeds - Bulbs - Plants

1202 Cook Avenue Lakewood, Ohio BOulevard 3566

E sincerely thank our customers and friends for their patronage in the past, and in the future we shall earnestly strive to continue holding the good. will already established by adhering to our policy of THE BEST in everything we sell.

In offering you this list, we are fully acquainted with everything offered herein, and unhesitatingly recommend the varieties of seeds and plants listed as being of the best. At the same time we shall be very glad to secure for our customers any varieties not catalogued.

We assure new customers and old, that all orders, large and small, will be given prompt attention at all times.

EARLY OFFERING: Your cooperation is invited by placing orders early. This will help us to facilitate delivery at the proper time.

RUSH ORDERS: May be telephoned or telegraphed at our expense.

BUSINESS TERMS: Prices quoted in this catalog are net, 30 days. All goods are offered, subject to being unsold on receipt of order, and we reserve the right to change prices, if current conditions require it.

ALL GOODS travel at purchaser's risk after they are in the hands of any common carrier.

ORDERS from unknown parties must be accompanied by cash or satisfactory references.

CLAIMS must be made on receipt of goods, otherwise they can not be considered.

PACKING will be charged extra at cost.

NON-WARRANTY: Wm. E. Attwood Co. gives no warranty, express or implied, as to descriptions, quality, productiveness or any other matter of any seeds, bulbs, or plants they sell, and will not be responsible for the crop. If the customer does not accept the goods on the above terms, they must be returned at once, and the money will be refunded or proper credit given. We exercise, however, the grea!est care in filling our orders, and use only the highest quality goods possible as it is our constant aim to give our customers fullest satisfaction.

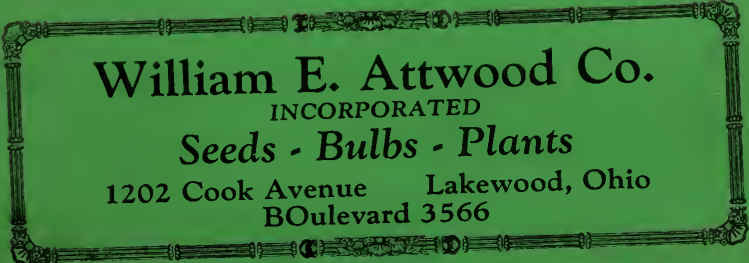




\title{
Specialties and Novelties in FLOWER SEEDS VEGETABLE SEEDS SHRUBS and PLANTS FLOWER SEEDS
}

\section{ASTERS}

AURORA. This aster is a real innovation. The center of the flower is bright yellow, with an outer circle of delicate blue, forming a very striking contrast. The plants are of robust growth, aver-

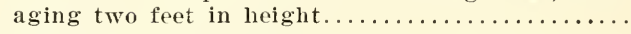

GIANTS OF CALIFORNIA (Single). This wonderful aster was developed out of the Double Giants of California and was offered for the first time last year. The flowers are large, measuring 3 to 4 inches across-with 18-24 inch stems. The petal has a sliglit twist, which adds to its beauty. We believe this new single type of aster is destined to become very popular. Offered in the following colors:

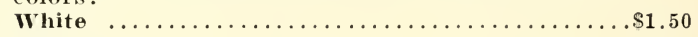

Rose ................................ 1.50

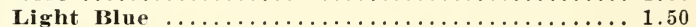

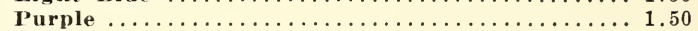

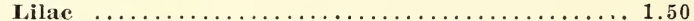

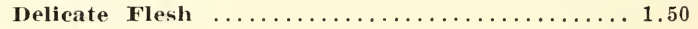

\section{CALENDULA}

RADIO. This unique new flower is a recent introduction from Europe. The true Radio form is a medium sized orange flower with quilled or comet petals, curled and twisted, borne on mediun length stems. Equally fine for the garden or for forcing.................\$0.75

\section{COSMOS}

HOLLYWOOD STAR. For those looking for odd and striking flowers, we recommend this uovelty. The flowers are pink, red and white, borne on long stems-makes a fine cut flower. The center of the flower resembles a scabiosa from which project eight petals set well apart in a star-like formation................\$0.50

\section{DAHLIA}

COLTNES IYBRIDS IMPROVED. The colouring of these selected hybrids is very comprehensive, ranging from deep crimson to white, and embracing delicate pinks and roses, as well as vellows, mauves and various sliades of scarlets and purples. The habit of the plant is also improved, being dwarfer and more compact, so that we have no doubt that our selection will increase the favor with which this charming class of Dahlias is already regarded.................\$4.00 $\$ 0.75$

\section{GODETIA}

\author{
75
}




\section{FLOWER SEEDS-Continued}

\section{HELIANTHUS}

Pkt.

MAROON PRINCE. This Helianthus is a dwarf growing strain. It is a true maroon in color, single, and is unduestionably the best red sunflower on the market

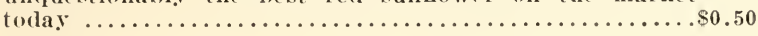

\section{LARKSPUR}

LA FRANCE. The mienue feature which differenti ates it from older types of Larkspur is its large number of long stemmed latrals from the crown stem. Ia France is very floriferous, the large, well formed, double flowers being well placed on the long stems. It is a vigorous grower and much more resistant to mildew than the older stock flowered varieties. Flowers are a pleasing salmon pink. We consider it a real achievement in the Hower world ........................\$1.00 \$0.50

Los INGELES. This variety was developed in response to the demand for a Larkspur of the same growing habit as La France, but with a richer color. The color of Los Angeles is a rich salmon ground, overlaid with a brilliant and pleasing rose. The type of growth is similar to La France, but the foliage of Los Angeles is a much darker green, making the large double flowers stand out

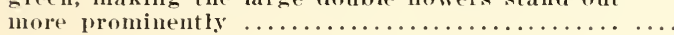

\section{MECONOPSIS BAILEYII}

(One of the finest introductions of recent years.)

5 Pkts. l'kt.

It is a beautiful hlue, perennial poply-well furnished with broad sea green leaves and bearing freely large 4-petaled blooms of a glorious sky blue color-the effect of which is enhanced by a central zone of golden yellow anthers.........\$3.50 $\$ 0.75$

\section{SALVIA}

5 Pkts. Pkt.

SPLENIENS HARBINGER. I'lants raised from seed sown at the end of February commence to produce in profusion their long spikes of dazzling bright scarlet flowers early in June, and maintain a blaze of color until the frosts. The plants are dwarf and compact in habit and the strong dark foliage forms an effective foil to the vivid liue of the flowers....................\$3.50 \$0.75

\section{VEGETABLE AND FARM SEEDS}

\section{BEET}

CHFLTENHAM GREEN LEAVED. Specially se-

O7. $1 / 407$. lected stock. This variety has very dark red flesh, free from the earthy taste which spoils some varieties. We consider this one of the best globe

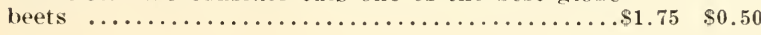

\section{SQUASH}

THE ZCCCHINI. This variety is undoubtedly the best of the Italian marrow squashes-growing much shorter and nore uniform in size than other types-and is better adapted for cooking. The American public is just learning of their delicious qualities and their superiority over the other well known sunmer squashes. skin is dark green...\$0.60 \$0.25 


\section{MANGEL WURZEL}

\section{Kirche's Pedigreed Ideal}

This Mangel combines the advantages of Heavy Yield, Highest Sugar Content, Highest Digestible Dry Matter, Easiest Harvesting, Best Keeping Quality and Fitness for Silage. We have kept constant check on this variety for the past four years and our records show it is superior to any Mangel now on the market. Our customers who consider "Kirche's Ideal Mangel" the outstanding variety and who have grown it two years or more with great success include Ralph W. Theime, Wabeno, Wis.; C. E. Ely, Mgr. Beardsley Farms, Garrettsville, Ohio; Nate Hill, Mgr. Halfred Farms, Chagrin Falls, Ohio: John McQueen, Supt Glengarry Farms, Chagrin Falls, Ohio; J. H. Skinner, Dean, School of Agriculture, Purdue University, Indiana, and many others.

Kirche's Ideal Mangel is cylindrical in shape, flattened at top and bottom, grows two-thirds to three-quarters above ground. The single top root makes easy and clean harvesting. It has a vellow skin and pure white, crisp, sweet interior tissue. An interesting four-page pamphlet dealing with the cultural and growing habits of this mangel will be gladly sent on request.

The seed is imported by us from Gernany in original sealed bags and sells for

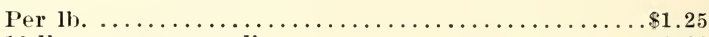

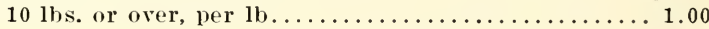

\section{NURSERY STOCK SPECIALTIES}

This stock herewith offered is extra fine specimen plants grown by a Lakewood Nurseryman with a reputation for prolucing unusual and well grown nursery products. Packing at cost. Truck delivery within 50 mile radius of Cleveland at cost.

\section{AZALEAS}

MIOENA. Evergreen. Conspicuous purple red

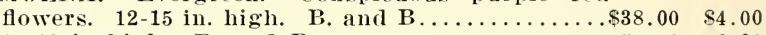
15-18 in high. B. and B....................

YODOGAwA. Double pinkish, lavender flowers. Very hardy and of exceptional merit. 18-24 in.

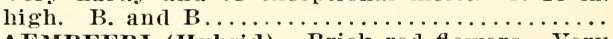

KAEMPFERI (Hybrid). Brick red flowers. Tery hardy. 15-18 in. high. B. and $\mathrm{R}$.

SCN STAR (Kurume). Good bright pink. Extra fine. 18-24 in. high. $R$. and $R \ldots \ldots \ldots \ldots \ldots \ldots$

DAYBREAK. Shell pink, a really fine Azalea. $18-24$ in. high. B. and B.................... 11.00

CALENDULACEA (Nursery Grown). Native in the Carolina Mountains. Very showy, burnt orange flowers. 18-24 in. high. B. and B........ 7.50

ARBORESCENS. Fragrant white flowers known as Sweet Azalea. $2-3 \mathrm{ft}$. high. B. and B......... 8.50

\section{HYBRID RHODODENDRON}

F. L. AMES (Amphion). Pink, white center, mammoth flowers. 18-24 in. high. B, and B............\$12.00

CATAWBIENSE ALBUM. Pure white, very fine. 18-24

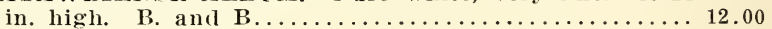

IGNATIUA SARGENT. A fine deep pink. 24-30 in. high.

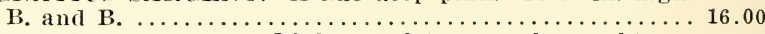
ROSEUM ELEGANs. Light scarlet, a much sought va-

riets. 24-30 in. high. B. and B............. 16.00

\section{CORNUS}

FLORIDA. White flowering Dogwood. One of the best

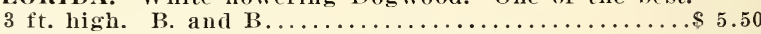
Extra fine specimens. $4 \mathrm{ft}$. likh. B. and B........ 7.50

Extra fine specimens. $5 \mathrm{ft}$. high. B. and B........ 9.00 


\section{CORNUS-Continued}

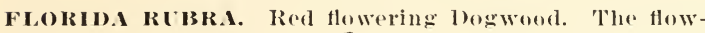
ers are more persistent than the white. 4-5 ft. high.

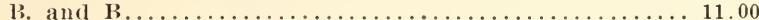

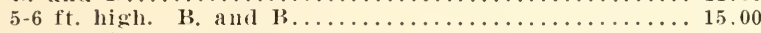

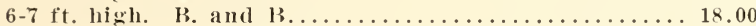

\section{CRATAEGUS}

PYR ICATTHA LELANDI. Evergreen fire Thorn. A beautiful broad leaved evergreen with large elusters of orange berries in the fall. Needs protection in the north. 18-24 in. high. B. and B............... 5.00 CORIDAX. Berries small, brilliant red. Brilliant autumn foliage. $5-6 \mathrm{ft}$. high. 13. and $13 \ldots \ldots \ldots \ldots \ldots \ldots \ldots 7.50$

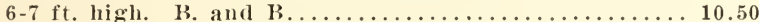

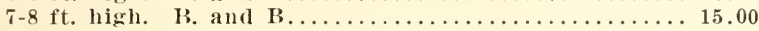

P.ILI. Double searlet flowers. (Pauls Searlet Haw-

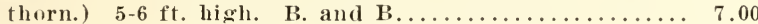

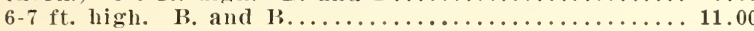

\section{FAGUS}

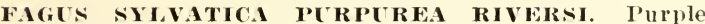
beech, tine specimens. $8-10 \mathrm{ft}$. higl............\$20.00

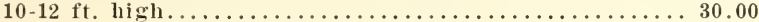

\section{DAPHNE}

CNEORUM. Evergreen, gray-green foliage, low spreading, pretty pink flowers in April and May. Very fragrant. 8-10 in. spread. B. and B.............. 3.00

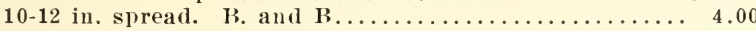

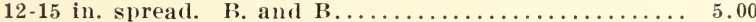

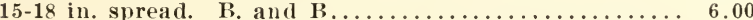
These are the finest specimens we have ever secn.

\section{HALESIA}

TETRAP'TERA GREIT SILVER BELI. Snow white bell shaped flowers in May. Profusely borno along the branchlets. 4-5 ft. high. B. and $\mathrm{B} \ldots \ldots \ldots \ldots \ldots \ldots \ldots \ldots \$ \ldots .00$

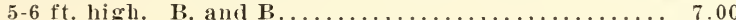

\section{ILEX}

GLAIBRA (Nursery Grown). Evergreen, shining dark green leaves, purplish in winter, black berries. Useful for shady spots. $15-18 \mathrm{in.} \mathrm{high.}$

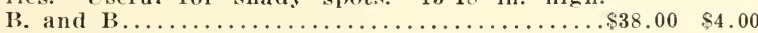
18-24 in. high. B. and B............. $40.00 \quad 4.75$

OPACA (Nursery Grown). Evergreen, does best in moist partially shaded place. 2-3 ft. high.

13. and $\mathrm{B} . \ldots \ldots \ldots \ldots \ldots$

\section{MAHONIA}

ACIIFOLIUM. Evergreen, shining green leaves turn rich scarlet in autumu. Striking in May when vellow flow ers appear. Blue black fruits. Succerds best in half shade. $15-18$ in. high. B. and B.............. 3.00

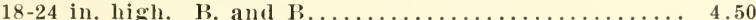

\section{MAGNOLIA}

SOCLANGEANA. Large purplish pink and white flowers in May. Best transplanted in early spring. $2 \mathrm{ft}$

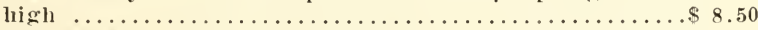

STFLLAT. Spreading shrubby habit, fragrant semidouble white flowers appearing long before the leaves.

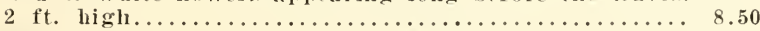
I. EN EI. A late bloomer, dark red in rolor, "xtra fine.

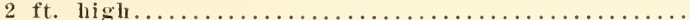

\section{ACER}

Japanese Maple

PALMATIM ATROPURIURECM. A good dwarf tree with rich purple-red leaves all summer. 'These offereal are grafted stock. $2 \mathrm{ft}$. high ................\$ 9.00

\section{PACHYSANDRA}

JAPANESE SPURGE. Fatra fine $2 \frac{1}{2}$ in. potted 


\section{General List of Attwood's Pedigreed VEGETABLE SEEDS}

\section{ARTICHOKE}

One ounce will sow 100 feet of row.

Peck Pkt. Oz.

LARGE FRENCH GLOBE. . . . . . . . . . . . $\$ 0.15 \quad \$ 1.25$

JERUSALEM TUBERS $\ldots \ldots \ldots \ldots \ldots \ldots \ldots \$ 3.00 \quad \ldots \ldots \ldots$

ARTICHOKE PLANTS-See Page 13.

\section{ASPARAGUS ROOTS}

See Page 13.

\section{BEANS}

Dwarf or Bush

\section{GREEN-PODDED VARIETIES}

One pound will plant 50 feet of drill.

BLACK VALENTINE. An extra early round

Lb. $5 \mathrm{lbs} .10 \mathrm{lbs}$.

podded variety of excellent quality.

$\$ 0.55 \quad \$ 2.50 \quad \$ 4.75$

BOUNTIFUL. For a really high quality greell podded snap bean we place Bountiful at the head of the list. Very early, vigorous and productive, with long, thick, flat pods, entirely stringless and light

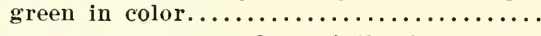

FULL MEASURE. One of the best green beans, early, productive high quality, with long, fleshy, round pods...................60

REFUGEE 1,000 TO 1. Medium late, round pods. A good variety for canning.........

MASTERPIECE. An English variety used extensively in this country as a forcing sort on private estates..................90

\section{WAX PODDED VARIETIES}

Lb. 5 lbs. $10 \mathrm{lbs}$

IMPROVED GOLDEN WAX. Old standard variety, pods fairly long, nearly round, bright yellow, stringless............... \$0.50 $\$ 2.25 \quad \$ 4.25$

PENCIL POD BLACK WAx. Desirable variety at the head of the list of long, round podded wax beans, clear yellow in color, highest quality ........................

WARDWELL'S KIDNEY WAX. Old favorite, pods large, broad, flat, fine grained,

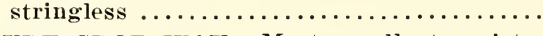

SURE CROP WAX. Most excellent variety, entirely stringless with long, thick, flat

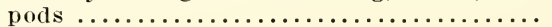

\section{LIMA BEANS \\ Dwarf or Bush}

BUSH LIMA, FORDHOOK. A most excellent variety more generally growu than any other sort. Very productive with large pods containing 4 to 5 large, oval, very thick, white beans..................\$0.60

HENDERSON'S BUSH LIMA.

ENGLISH BROAD BEAN. A well known productive variety used the same as Lima Beans

\section{POLE BEANS}

Lima, Etc.

POLE LIMA, CARPENTERIA. A vigorous productive variety which retains its green color in the seed.....................\$0.60

SCARLET RUNNER POLE BEANS. On the order of Lima beans, grown also for the ornamental, bright, searlet flowers........

STEAD. Pods green, very long, stringless.

$\begin{array}{lll}.50 & 2.25 & 4.25 \\ .50 & 2.25 & 4.25\end{array}$




\title{
BEET
}

One ounce will sow 50 feet of arill.

$$
\text { I'kt. Oz. 1/4 lb. Lb. }
$$

CROSIBY'S EARLY EGYPTIAN. lioots

uniform, flattened globe in shape,

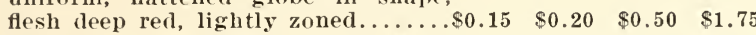

DETROIT DARK RED. Best Main

Crop. Roots medium size, globe shape, very smooth, vermilion red. Our stock of this variety shows no

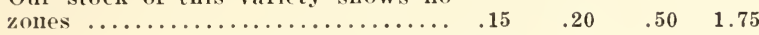

SWISS CHARD

GIAN LUCULLUS. An improvement Pkt. Oz. 1/4 lb. Lb. on the old variety, foliage much crumpled or savoyed............. \$0.15 $\$ 0.20 \quad \$ 0.50 \quad \$ 1.75$

\section{MANGEL WURZEL}

\author{
Sow 6-8 lbs, to acre.
}

KIRCIES IDEAL. See Specialties, Page 4.

\section{BORECOLE or KALE}

One ounce of seed will sow 100 feet of row.

Pkt. Oz. 1/4 lb.

DWARF CURLED GREEN SCOTCH. Very

dwarf and spreading. Leaves densely

erisped and curled. Hardy and produc-

tive ............................... $\$ 0.15 \quad \$ 0.25 \quad \$ 0.70$

\section{BROCCOLI}

A vegetable similar to Cauliflower, of less delicate flavor, but hardier.

ITALIN GREEX SPROUTING. (Verona.)

This variety of Broceoli lias recently be-

come very popular; is preferred by many

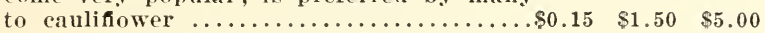

\section{BRUSSELS SPROUTS pkt. oz.}

DALKEITh. Produces large, solid sprouts of finest flavor ............................. $80.15 \quad \$ 0.40$

PROLIFIC Exhibition. Very fine, even-shaped sprouts of good size and flavor; splendid for

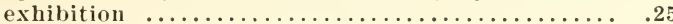

\section{CABBAGE}

One ounce will produce 3000 plants.

Pkt. Oz. 1/4 lb

COPENHAGEN MARIEET. Lndoubtedly the most valuable cabbage of recent introduction, maturing but a few days later than Jersey Wakefield. Exceptionally large, round, solid, white heads. Our stock of this variety is unsurpassed..............\$0.15 $\$ 0.60 \quad \$ 2.00$

EARLY JERSEY WAKEFIELD. The earliest and most sure-heading of the early

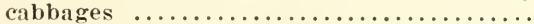

DANISH BALLHEAD. More largely grown for winter storage than any other sort. Hearls medium size, round and exception-

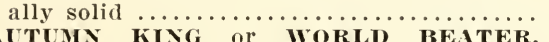

IUTUMN KING or WORLD BEATER. ily. Late maturing, flat heads............

GOLDEN ACRE. A wonderful fine extra early, round headed variety on the order of Copenhagen Market. Small, compact, earlier than Jersey Wakefield.............

SUREIEAI). An exceptionally fine, depend-

able cabbage of the Flat Dutch type.......
SiVoy, PEREECTION bRU1H EiI. The best winter-keeping Savoy type, late,

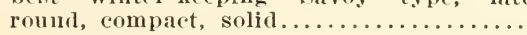

\section{CHINESE or CELERY CABBAGE}

PE-TSAI. This delicious Chinese regetable belongs to the cabbage family and closely resembles a cos lettuce but is heavier. It may be eaten raw as a salad or boiled like cabbage 


\section{CARROTS}

One ounce will sow $100 \mathrm{ft}$. of drill.

Pkt. Oz. $1 / 4 \mathrm{lb}$. Lb.

DANVERS HALF LONG. Splendid orange carrot, grown for its productiveness and adaptability to all soils. Roots 6 to 8 inches, deep

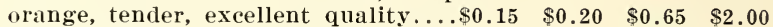

CHANTENAY. An excellent, produc$\begin{array}{lllll}\text { tive, half-long, medium early variety } & .15 & .25 & .65 & 2.00\end{array}$

OXHEART. Roots very stout and thick, of medium length, ending in an abrupt small tap root...........

FRENCH FORCING HORN. Earliest variety with nearly round, orange colored roots ....................

IMPROVED LONG ORANGE. The old standard variety, roots about 12 inches long and of deep orange color

$\begin{array}{llll}.15 & .25 & .65 & 2.00 \\ .15 & .25 & .65 & 2.00 \\ .15 & .25 & .65 & 2.25 \\ & & & \\ .15 & .20 & .65 & 2.00\end{array}$

\section{CAULIFLOWER}

EARLY SNOWBALL. Undoubtedly the best Plit. $1 / 4 \mathrm{oz} . \quad \mathrm{Oz}$. and most popular early variety. Medium size snow white heads, firm, compact, solid.\$0.50 $\quad \$ 1.75 \quad \$ 5.25$

DRY WEATIER. A fine variety similar to Snowball; adapted for dry locations.......... $.25 \quad 1.50 \quad 4.75$

EARIY IVARF ERFURT. An excellent early sort producing good-sized, ereamy-

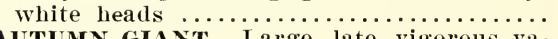

AUTUMN GIANT. Large, late, vigorous va-

riety, having large, firm, white heads....

$\begin{array}{lll}.75 & 2.50 & 8.00\end{array}$

\section{CELERY}

One ounce of seed will produce 5000 plants.

GOLDEN SELF BLANCHING. Without doubt the finest early celery. Compact and stocky, nutty

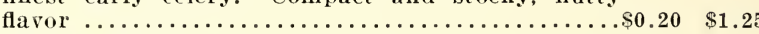

GIANT PASCAL. Standard winter keeping. Broad, thick stalks that blanch a beautiful creamy white $\quad .15 \quad .60$

IMPROVED WHITE PLUME. Popular very early

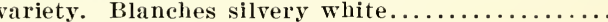

WINTER QUEEN. A storage variety of medium

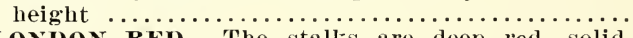

LONDON RED. The stalks are deep red, solid, crisp and of a fine nutty flavor................25

\section{GELERIAG or TURNIP ROOTED CELERY}

$\begin{array}{lll} & \\ & & \end{array}$

L.IRGE sMOOTH PRAGUE............... $\$ 0.15 \$ 0.50$

\section{CHERVIL}

One ounce will sow 150 feet of drill.

EXTRA CURLED. Beautifully curled, leares re-

semble parsley. Used for flavoring soups and

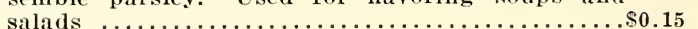

\section{CHICORY}

WITLOOF or FRENCH ENDIVE. The stalks when

$\$ 0.15 \$ 0.50$

\section{CRESS or PEPPERGRASS}

One ounce will sow 150 feet of drill.

EXTRA CURLED. The leaves make a de-

Pkt. Oz. Lb.

licious salad .............................15 $\$ 0.25 \quad \$ 3.25$

TRUE WATER CRESS. For growing in

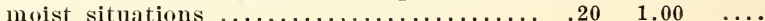




\section{CORN}

One pound will plant 100 hills. Lb. $5 \mathrm{lb} .10 \mathrm{lb}$.

GOLDEN BANTAM. The standard quality sweet corn, fairly early in season, rather dwarf growth, golden yellow grain........ \$0.40 $\$ 1.85 \quad \$ 3.50$

STOWELL'S EVERGREEN. The best known main erop sweet corn. Tall, vigorous grow-

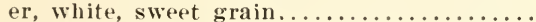

GOLDEN SUNSHINE. Early Golden Bantam type, maturing a week or ten days earlier than the type. Especially desirable for its extreme earliness................... COUNTRY GENTLEMAN. Exceptionally fine quality corn, cob small, densely covered with long, slender grains without row formation ..........................

\section{CUCUMBER}

One ounce will plant 50 hills.

EARLY ForTUNE. White Spine type, early, very productive, nearly disease resistant. Very few seeds ..............................................

EARLIEST OF ALI. One of the very earliest and IVIS PER FECT. Extra long, dark green, White

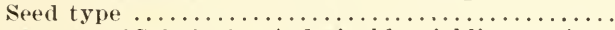

Boston PICKLING. A desirable pickling variety, most productive, short, thick, smooth fruit..... .15

WEST INDIA GHERKIN. Grown exclusively for pickles. Small, oval, covered with spines.......... .15

WHITE SPINE ENTRA LONG. An improved type .15

IMPROVEI TELEGRAPH. The best foreing type. .50

\section{EGGPLANT}

BLACK BEAUTY. Early, dark purple.........\$0.15 NEW YORK IMPROVED PURPLE. Spineless.... .15

Oz.

.30

.30

$\cdots$

$\$ 0.80$

\section{ENDIVE}

One ounce will sow about 100 feet of drill.

$$
\text { I'kt. O\%. 1/4 lb. }
$$

BROAD-LEAVED BATAVIA. Leaves broad,

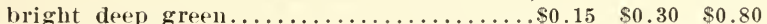

MOSS CURIED. More compact than other

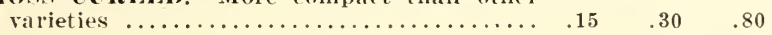

\section{KOHL RABI Pkt. O\%. 1/4 lb.}

EARLY WHITE VIENNA. White skin, fine

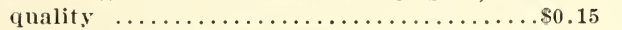

EARLY PIRPIe VieNNi. Purple skin,

white flesh ...................... .5. $50 \quad 1.50$

\section{LETTUCE}

One onnce will sow 100 feet of drill.

WONDERFCL. A late, large, globular head-

$$
\text { Plit. Oz. } 1 / 4 \mathrm{lb} \text {. }
$$

ing sort .........................

SELECTED (ARANI) RAPIDS. Leaves blist-

ered and crumpled..........................

head lettuce. Heads large and compact...

ICEBERG. Popular for home garden. Heads

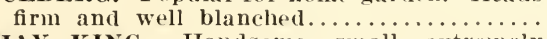

M.AY KING. Handsome, small, extremely

early, compact heading..................
mIGNoNET'E. Small, very early, crisp and

BLACK SEEDED simpsox. One of the

best early loose-heading sorts...............
W.YMEA I. Very early, small, handsome, compact heading, superior quality...........

P.IRIS WIITE COS. Long, smooth, narrow,

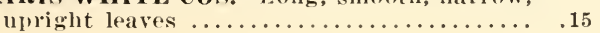




\section{LEEK}

One ounce will sow 200 feet.

Pkt. Oz. $1 / 4 \mathrm{lb}$.

BROAD AMERICAN FLAG. The favorite variety, strong growing broad leaved and productive $\ldots \ldots \ldots \ldots \ldots \ldots \ldots \ldots \ldots \ldots \ldots \ldots . \$ \ldots .15 \quad \$ 0.50 \quad \$ 1.50$

\section{MELONS-MUSK}

One ounce will plant 60 hills.

BENDER's SURPRISE. Popular, adaptable variety. Oblong, full, and rounded at the ends. The skin when ripe is light greenish yellow, flesh a very

deep salmon $\ldots \ldots \ldots \ldots \ldots \ldots \ldots \ldots \ldots \ldots \ldots \ldots \ldots \ldots \ldots \ldots$
EMERALD GEM. One of the earliest good quality melons of medium size, irregularly ribbed and lightly netted, flesh thick, deep orange color....

HEARTS OF GOLD. Small inid-season variety, fruit round, distinctly ribbed, densely netted,

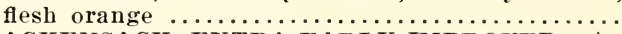

HACKENSACK, EXTRA EARLY IMPROVED. An early selection from the old Hackensack, smaller

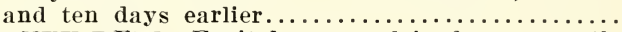

HONEY DEW. Fruit large, oval in form, smooth, hard, lemon-tinted shell, without ribbing or net-

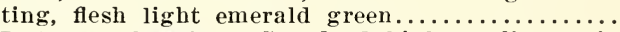

MILLER'S CREAM. Standard high quality main crop melon. Fruit dark green, slightly ribbed and netted, flesh salmon, thick and sweet.........

WATERMELON, COLE'S EARLY. One of the very earliest and of excellent quality. Fruits medium size, oval, flesh bright red, sweet and tender.....

ENGLISH FORCING VARIETIES

SUTTON's BEST OF ALL. Flesh very thick, deep

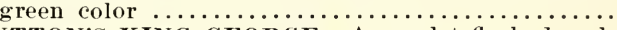

SUTTON'S KING GEORGE. A scarlet-fleshed mel-

on. Skin buff yellow, very tine............... 1.00

MUSHROOM SPAWN

Ten bricks will spawn about 10 feet square. AMERCAN PURE CULTURE. Per brick............. \$0.40

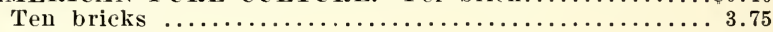

\section{MUSTARD}

WHITE LONDON. The best variety for salad

Pkt. Oz. $\quad 1 / 4 \mathrm{lb}$ $\ldots \$ 0.15 \quad \$ 0.25 \quad \$ 0.75$

\section{OKRA or GUMBO}

One ounce will plant 100 hills.

Pkt. Oz. 1/4 lb.

WhITE VELVET. Pods long, white color. $\$ 0.15 \quad \$ 0.30 \quad \$ 0.90$

\section{ONIONS}

One ounce will sow 100 feet of drill.

Pkt. Oz. 1/4 lb.

SOUTH POR T GLOBE, Y ELLO W and WHITE. The Southport type of Globe onions are more extensively grown than other varieties because of their fine form, good color and excellent keeping qualities.\$0.15 $\quad \$ 0.75 \quad \$ 2.50$

AILSA CRAIG. An exhibition variety of large size, sometimes weighing over three pounds each. Bulbs oval, pale straw-col-

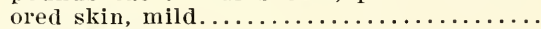

PRIZETAKER. One of the best, mildest, and surest to grow from seed...............

YELLOW GLOBE DANVERS. Popular de-

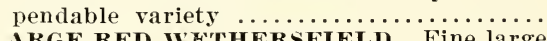

LARGE RED WE'THERSFIELD. Fine large

flat sort $\ldots \ldots \ldots \ldots \ldots \ldots \ldots \ldots \ldots \ldots \ldots \ldots, .15 \quad .60 \quad 2.00$

\section{ONION SETS}




\section{PARSLEY}

One ounce will sow 150 feet of trill.

$$
\text { I'kt. Oz. } 1 / 4 \mathrm{lb} \text {. }
$$

CHAMPION MOSA CURLED. Leatres nutform deep green, tinely cut and so closely

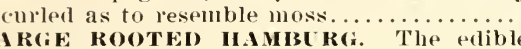

L.IRGE ROOTED IAMBST(i. The edible
roots resemble a small thick parstip and are llsed for flavorillg solus...............

\section{PARSNIPS}

One ounce will sow 200 feet of drill.

HOLLOW (CROWNED. More generally P'kt. $0 \% \quad 1 / 4 \mathrm{lb}$. grown than any other sort. lioots large,

smooth, temder, aud sumiry...........\$0.15

\section{PEAS}

EXTRI EARLY VARIETIES

One pound will plant 50 feet of drill.

Not'T's EXcelsior. An old, standiard, extra early, dwarf pea, producing an abundance of well filled pods...........\$0.40 $\$ 1.75 \quad \$ 3.25$

MMERICAN WONIER. Standard variety, very dwarf, extra early sweet pea........

LITTLE MARVEL. Exeeptionally productive, early, high quality straight pods four

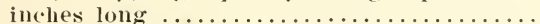

BLIE BANTAM. Splendid, large-podded dwarf variety, of the Laxtonian class, stout healthy growth, abundance of large sweet

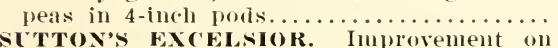
Nott's Excelsior, larget pods, more produc-

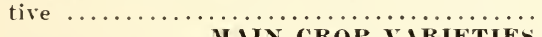

DWARF TELEPHONE. Excellent main erop variety, large handsome deep green pods.. QUITE CONTENT. An exhibition valiety, long broad pods of the Alderman type....

$\begin{array}{lll}.40 & 1.75 & 3.25 \\ .45 & 2.00 & 3.75 \\ .50 & 2.25 & 4.25\end{array}$

\section{PEPPERS}

One ounce will produce about 2000 plants.

IIARRIS' EARLIEST. This valriety is something quite distinct in peppers. Not only is it the earliest, but it is also a better formed variety, excesdingly productive and of good marketable size. Very mild and

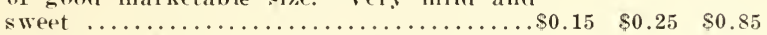

CHINESE GINNT. Large, mild, distiuct in its short, blocky, almost square form. The fruit when ripe is a brilliant glossy sarlet

LONG RED COYENNE. The 5 -iuch fruits are bright red, hot and pungent...........

RED CHILI. Exceedingly prolific, very hot variety, used for pepper sallce............. $.15 \quad .30 \quad 1.00$

\section{POTATOES}

Ten bushels cut tubers will plant one acre.

F.IRLY Rose. Early, very productive.... ?

GRELN MOUNTIIN. A tine late variety... At Market Prices IRISII COBBLER. Medium early.........

\section{PUMPKIN}

One ounce will plant 50 hills.

KING OF TIE MAMMOTHS. The giant among pumpkins. Exhibition specimen liave been grown to weigh 100 pounds..... \$0.20 $\$ \$ 0.60 \quad \$ 1.75$

IA RGE CHEEsE. Fruits large, round, flattened, creamy buff, flesli yellow. very deep,

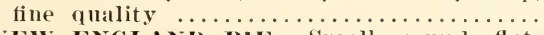

NEW ENGLANI) PIE. Snatl, rome, flattened, sliglitly ribbed, skin and flesh deep orange-yellow color, thesh thick and of high (juility 


\section{RADISH}

One ounce will sow 100 feet of drill.

S.Ix. The earliest of the radishes and one

Oz. $1 / 4$ lb. L.b.

of the most handsome, round, bright scar-

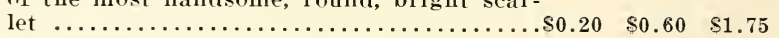

SCARLET GLOBE. General farorite, scar-

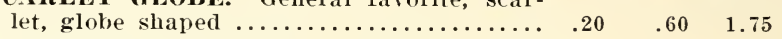

FRENCH BREAKFAST. Oblong, bright

rose, white tip......................... $.20 \quad .60 \quad 1.75$

ICICLE. Beautiful, long, white. Always

crisp and tender....................... $.20 \quad .60 \quad 1.75$

\section{SALSIFY}

One ounce will sow 75 feet of drill.

MAMMOTH SANDWICH ISLAND. Roots

Pkt. Oz. $1 / 4 \mathrm{lb}$.

three times the size of ordinary Salsify,

white, agreeable fiavor................... $\$ 0.15 \quad \$ 0.60 \quad \$ 1.75$

\section{SPINACH}

One ounce will sow 100 feet of drill.

$$
\text { Oz. } \quad 1 / 4 \mathrm{lb} \text {. Lb. }
$$

LONG SEASON. Flat rosette, dark green, crumbled, broad, pointed leaves...........\$0.15 $\$ 0.30 \quad \$ 0.75$

NEW ZEALAND. Distinct from the true Spinach. Plant Iowarf spreading with numerous side shoots. Grows well in hot weather and under adverse conditions....

VICTORIA. Dense, flat rosette, leaves round, thick, stands hot weather well.............

KING OF DENMARK. While the plants are ready for use as soon as most early sorts they remain in good condition two weeks after other sorts have gone to seed.......

\section{SQUASH}

One ounce will plant 30-40 hills.

GIANT SUMMER CROOKNECK. The largest and earliest of the summer varieties...............\$0.25 $\$ 0.75$

WHITE BUSH SCALLOPED. Very early, fruits creamy white .................................. $\quad .25$

IMPROVED IIUBBARD. Popular late variety.... $.35 \quad 1.00$

COCOZELLA OP ITALIAN VEGETABLE MARROW.

Fruits oblong, color dark green................ .40 1.25

\section{TOMATO}

One ounce will produce 1500 plants.

Pkt. Oz.

EARLIANA. Productive, first early red tomato....\$0.15 $\$ 0.75$

GLOBE. Productive, fairly early, smooth, solid,

purplish pink ............................... $\quad .75$

PONinerosa. Large, purple fruited, few seeds... $\quad .15 \quad .75$

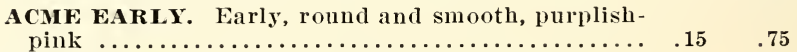

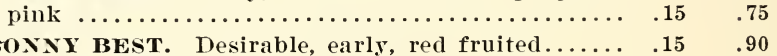

DWARF STONE. Best of the dwarf, solid, deep

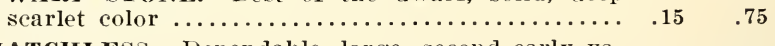

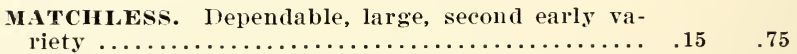

$\begin{array}{lllll}\text { STONE. Standard general favorite main crop, red. } & .15 & .75\end{array}$

SMAIL. FRUITING. Red Plum, Yellow Plum, Red
Currant, Red Cherry, Yellow

\section{FORCING VARIETIES}

CARTERS SUNRISE. Rich scarlet-a fine forcer........\$0.50

STIRLING CASTLE. A popular variety for forcing..... .50 


\section{TURNIP}

One ounce will sow 150 feet of drill.

E.IRI, SNOWB.LL. Exceedingly early, medium size, pure white skin and flesh...\$0.15 $\$ 0.25 \quad \$ 2.00$

EARLY WHITE MIL.N. Early, pure white skin and flesh........................... .15 .25 2.00

PLRPLE TOP WHITE GLOBE. Most desirable of the Turnily family. Globular, tine grained, sweet and tender.............. .15 $\quad .25 \quad 2.00$ RUTABAGA, AMERICAN PURPLE TOP. Fine productive strain................. .15 .25 2.00

\section{HERBS}

P'kt.

AXISE. Used for flavoring.................... $\$ 0.25$

CORIINDER. Seeds used for flavoring..............25

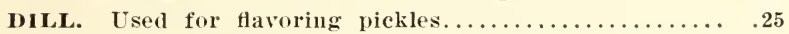

FLORENCE FENNEL. Bulb like vegetable formed at base of leaf stalk.......................... .25

LAVENDER. Leaves very fragrant...............25

SWEET MARJORAM. Ised as a seasoning............25

SAGE. Highly aromatic. Most useftil of all...........25

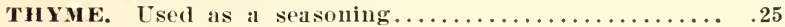

\section{ESCULEN'T ROOTS AND PLANTS} ASPARAGCS ROOTS

W.ISIINGTON. liust-resistant, vigorous and of wonderful quality. The shoots are large, straight and dark green in color. 3 -year-old..........\$4.00\$35.00

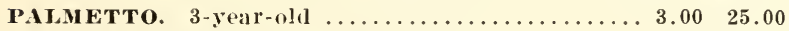
GIANT ARGENTECIL. 3-year-old............. $3.00 \quad 25.00$

IRTICHOKE PI YTs, Green (ilobe. $100 \quad$ Doz. CHIVE PLANTS ......................... 3.00

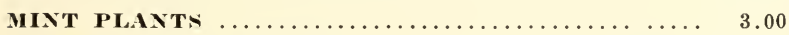

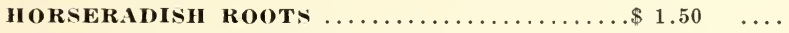

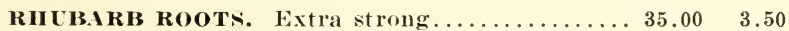
TARRAGON ROOTS. Extra strong............. 3.50

\section{Attwood's Pedigreed FLOWER SEEDS}

An Offering of Fine Selected Strains AGERATUM

\section{Floss Flower}

BLUE PERFECTION. Deep amethyst blue, compact growth, splendid bedder............. \$0.50 $\$ 0.15$ LITTLE BLUE STAR. Exceedingly dwarf and symmetrical growth, 4-5 inches, much used for carpet bedding and edging...................... 1.00

\section{SWEET ALYSSUM}

CARPET OF SNOW. One of the finest hor1/20\%. 10z. Pkt. der plants for all summer blooming. 'The plants begin to bloom while they are still small $\ldots \ldots \ldots \ldots \ldots \ldots \ldots \ldots \ldots \ldots \ldots \ldots \ldots \ldots \ldots \$ 0.60 \quad \$ 1.00 \quad \$ 0.15$ 


\section{ANTIRRHINUM \\ Snapdragon}

Pkt.

TALL MAXIMUM. The newest creation in snapdragons, a marked advance over the older tall, large flowered type in size and brilliancy of color. The flowers are closely

placed on the stem......................... 80.25

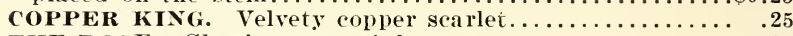

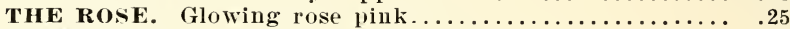

PURPLE KING. Deep, rich purple................25

CANARY BIRI. Canary yellow with golden center...... .25

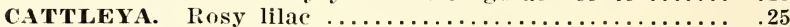

SNOWFLAKE. Pure white with yellow tube...........25

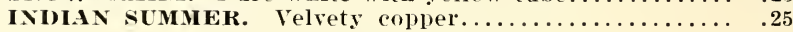

TALL LARGE FLOWERED

GOLDEN KING. Giant vellow.................... 20

FIRE KING. Orange and scarlet with white tube............20

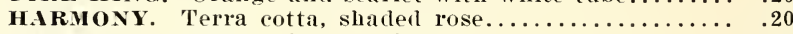

QUEEN VICTORIA. Pure white....................20

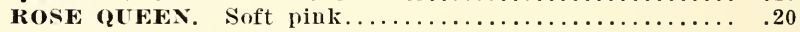

MEDICM LARGE FLOWERED

SILVER PINK. Pearly pink self.................. .15

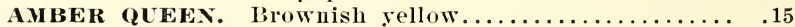

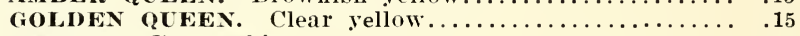

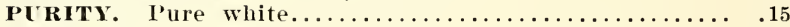

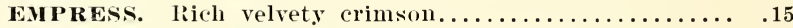

\section{GREENHOUSE VARIETIES}

HELEN. Beautiful salmon ..................... 1.00

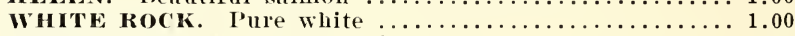

PHILADELPHIA PINK. Bright pink..............

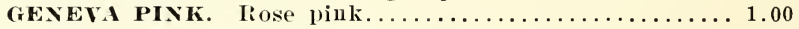

CHEVIOT MAID. Finest bright pink................. 2.00

AFTERGLOW. Salmon, bronze tinted..............2.00

\section{ARCTOTIS GRANDIS}

African Daisy

$1 / 4 \mathrm{oz}$. Pkt.

ilvery white flowers with blue center, fine for

cutting

\section{ASTERS}

GIANTS OF CALIFORNIA. One of the newer instructions in asters that has already become deservedly popular. Characterized by the well known Crego or Ostrich Feather type of flower with long, sturdy stems, and stands at the head of the Aster list.

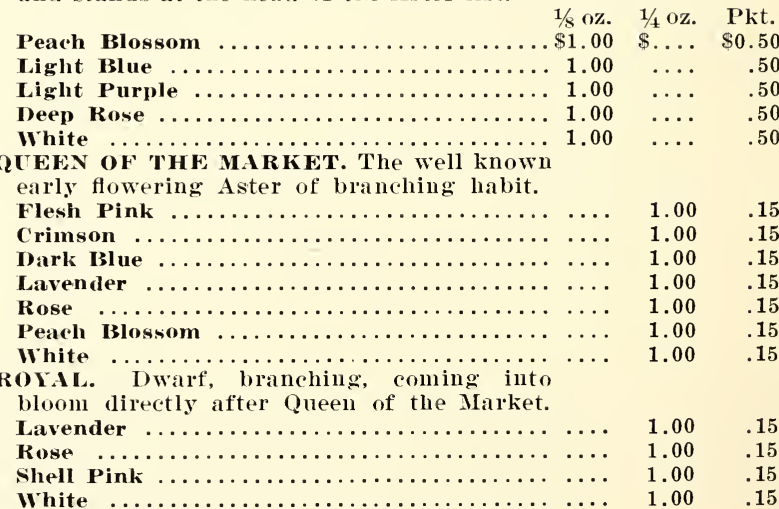

IMPROVED CREGo. Flowering in mid-season, the blooms are large, double, wellformed, of the Comet type.

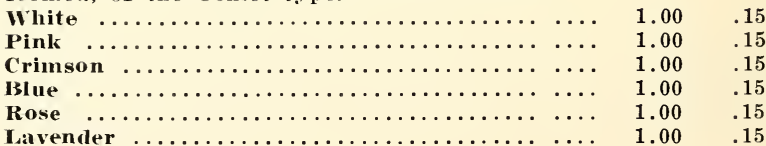

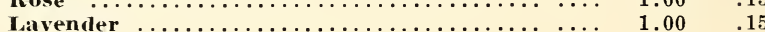




\section{ASTERS-Continued}

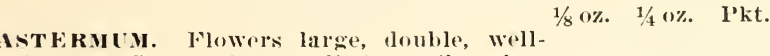

formed, Comet class, a little a rlier than

Crego.

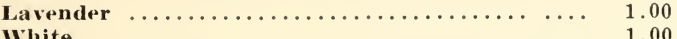

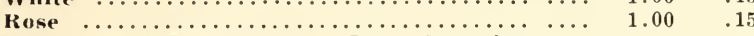

AUERICAN IBRANCHING. Late flowering

type, brauching and robust, flowers large,

perfectly double, of fine form.

Crimson

Blue ................................ $1.00 \quad .15$

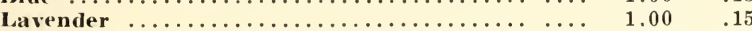

Rose

Peach .............................. $1.00 \quad .15$

White Perfection ....................... $1.00 \quad .15$

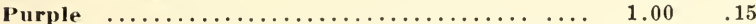

H E.I RT OF FR.INCE. Flowers medimm size,

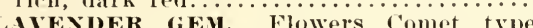

silvery white when young, changing to

light lavender when fully expanded....... $1.50 \quad \ldots . \quad .25$

B.ILL's WHITE. P'ure white, branching

habit, medium early.................. $1.50 \quad \ldots \quad .50$

SCNSIINE INEMONE FLOWERED. A

novelty among asters that is proving very popular. The blooms, like Anemone chrysinthemums, are borne on long, strong stems, and lend themselves well to cut flower arrangements.

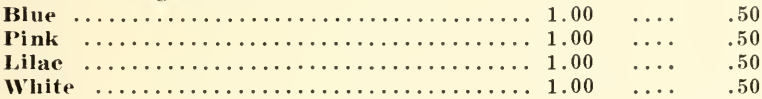

\section{BALSAM}

Lady Slipper

Brilliant masses of beatiful flowers for little care, the waxy blooms are tine individually or in groups.

1/4 oz. I'kt.

CIMELLIA-FLowERED. White Perfection ....\$ W0.60 \$0.15

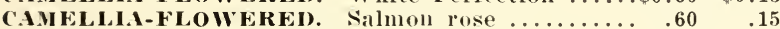

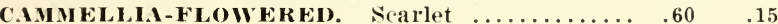

\section{BRACHYOME IBERIDIFOLIA}

\section{Swan River Daisy}

Attractive little plants of compact form with bright bhue Cinerarialike flowers. Siplendid as a border plant.

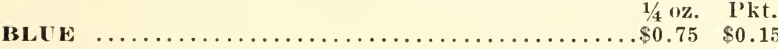

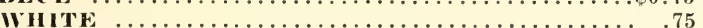

\section{BROWALLIA ELATA}

splendid little plants for borders or for the porch box. Profusion of bright blue flowers, the shade of blur one always needs more of in the garlen.

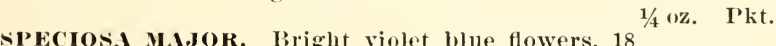

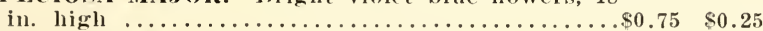

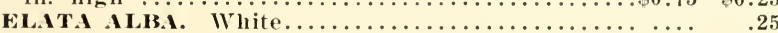

\section{CALCEOLARIA HYBRIDA GRANDIFLORA}

While this interesting plant may be grown easily out of doors in Englaud, it is best here as a pot plant. Tho wroat profusion of pocket-shaped flowers are gorgeously colored ............................. $\$ 1.00$

\section{CALENDULA}

Pot Marigold

We have only ball's strain as it is such an

improvement over all other kinds........\$2.25 $\$ 4.00 \quad \$ 0.50$ 


\section{CALLIOPSIS}

Indispensable for cut flowers with their rich colorings that range from golden yellow to mahogany brown.

DRUMMONDI. Golden yellow with brown 1/8 oz. 1/4 oz. Pkt.

center, 12 in................................ \$0.30 $\$ 0.15$

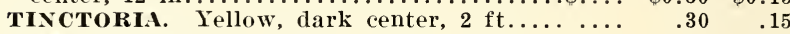
TOM THUMB "DAZZLER". Rich maroon

center with golden yellow border, 12 in... $1.00 \quad \ldots . \quad .50$

\section{CANDYTUFT}

Equally valuable for cut flowers or for borders. The blooms are well borne on strong stems and last well.

Oz. Pkt.

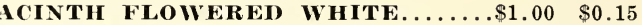

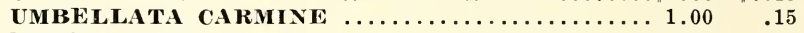

FLESH PINK $\ldots \ldots \ldots \ldots \ldots \ldots \ldots \ldots \ldots \ldots \ldots \ldots \ldots, 1.00 \quad .15$

\section{CARNATIONS}

CHABAUD'S EVERBLOOMING. These carnations are fully doubled, of great fragrance, splendid for cutting ................................ $\$ 1.00 \quad \$ 0.50$

MARGUERITE. Large, single flowers, borne on strong stems that need no support. Desirable for cutting or bedding.......................... 1.00

\section{CLARKIA}

Clarkias deserve to be grown more as their graceful stems of dainty flowers cannot be surpassed in cut flower arrangements. They thrive best in cool moist soil.

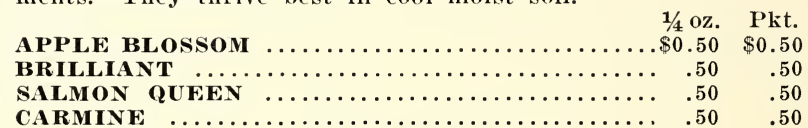

(1)

\section{CELOSIA}

\section{Coxcomb}

A popular annual of easy culture producing great heads of bloom in late summer.

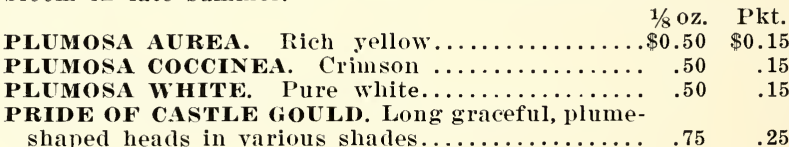

\section{CHILDSI}

Chinese Woolflower

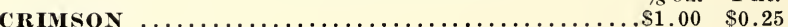

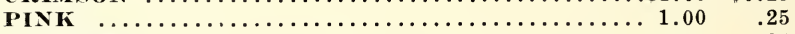

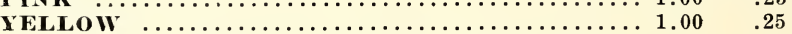

\section{CENTAUREA GYANUS}

These much loved annuals will never lose their popularity because they are so easily grown and come in colors unsurpassed for cutting.

\begin{tabular}{|c|c|c|c|}
\hline SIS & $\begin{array}{l}1 / 40 \% \\
\$ \ldots . .\end{array}$ & $\begin{array}{l}\mathrm{O} \% \\
\$ 0.75\end{array}$ & $\begin{array}{l}\text { Plit. } \\
\$ 0.15\end{array}$ \\
\hline LE BLUE & & .75 & \\
\hline E WHITE & & .75 & .1 \\
\hline $\begin{array}{l}\text { E BLUE } \ldots \ldots \ldots \ldots \ldots \ldots \\
\text { IALIS. (Sweet Sultan.) }\end{array}$ & .50 & $\ldots$ & .1 \\
\hline & .60 & • & \\
\hline Ro &. & . & .1 \\
\hline & .60 & $\ldots$ & .1 \\
\hline I F & .75 & $\ldots$ & \\
\hline $\begin{array}{l}\text { White, bread leaved } \\
\text { OCARPA. White, narrow leaved }\end{array}$ & $\begin{array}{l}.50 \\
.50\end{array}$ & $\cdots$ & .20 \\
\hline
\end{tabular}

\section{CINERARIA}

Popular greenhouse pot plants. 


\section{CHRYSANTHEMUM (Annual)}

$A$ cut flower that lasts well in water and is also attractive in the border.

MORNING sTAR. Primrose yellow with deep yel-

low border ................................ \$0.50 \$0.15

EVExIxG sTAR. Golden yellow with darker cen-

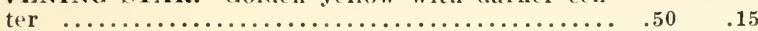

\section{COBAEA SCANDENS}

A magnificent rapid growing climber with bell-shaped purplish blue or white flowers.

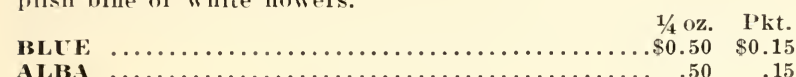

AIBA

\section{COSMOS}

LARGE FLOWERING VARIETIES

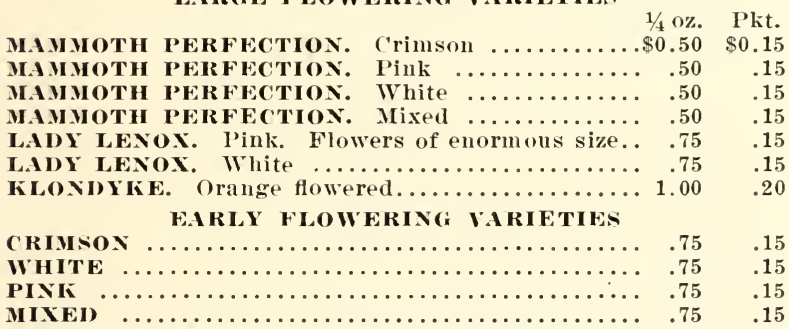

DOCBLE CRESTED. A new class prodncing double

flowers, beautifnlly crested and most striking in appearance.

Crimson King. A beautiful shade............. $1.50 \quad .20$

Pink Beauty. Shell-pink....................... $1.50 \quad .20$

White Queen. Pure white................... 1.50 .20

\section{CYNOGLOSSUM}

An elegant hardy anmual for beds or edgings, with glaucous green leaves.

SITTON's BLUE GEM. Brilliant blue Forget-me-not

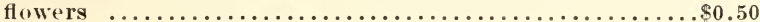

\section{DIANTHUS}

These beautiful plants, though really hardy biennials, do best when treated as half-hardy annuals, and may be had in bloom the same season if sown early. 12 in.

$$
\text { SINGLE VIRIETIES }
$$
purple eve ............................ $0.75 \$ \$ 0.15$ HEDIDWIGI, CRIMSON IBELLE. Brilliant velvety

crimson ............................. $75 \quad .15$

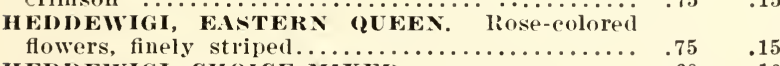

HEDIEWIGI, CHOICE MIXEI ................ .60 DOUBLE VARIETIES

CHINExsIs (Indian Pinks). Mixed..................

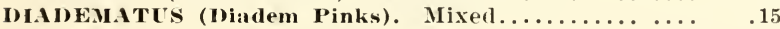

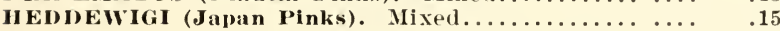

\section{DIDISCUS COERULEUS Blue Lace Flower}

This is one of the newest additions to the flower garden. The delicate lavender-blue flowers add crace to the daintiest bouquet........... $\$ 0.50 \quad \$ 0.15$

\section{DIMORPHOTHECA AURANTIACA \\ Gold Daisy}

Rare and showy annnal from South Africa with satiny orange flowers.

1/4 Oz. Pkt. ACRANTIACA IIYBRIDs. Colors include shades

primrose, buff, apricot and white..............60 


\section{ESCHSCHOLTZIA}

\section{California Poppy}

Hardy annuals with showy flowers - most effective when grown in beds. $12 \mathrm{in.}$

CALIFORNIA. Large vellow............... $1 / 40 z$ Pz. GOLDEN WEsT. Bright orange yellow..... .50 ... .15 IIK.ADO. Orange crimsom................

\section{EUPHORBIA}

HETEROPIYLLA MEXICAN FIREPLANT. Glossy green

and carmine leaves, $2-3 \mathrm{ft} \ldots \ldots \ldots \ldots \ldots \ldots \ldots \ldots \ldots \ldots \ldots . . . \ldots \ldots$

VARIEGATA. Green and white foliage............. .15

\section{GAILLARDIA}

\section{Blanket Flower}

Flowers a beautiful combination of shades varying between gold and niaroon.

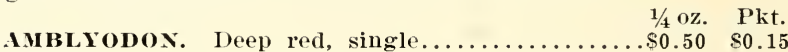

\section{GLOBE AMARANTH}

Popular everlasting flowers, 12 in.

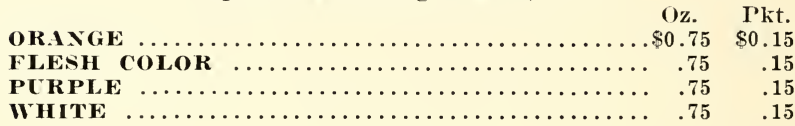

\section{GODETIA}

\section{Satin Flower}

A showy annual that seemis to thrive in the poor corner of the garden where other flowers fail. The colors range from bright carmines through the reds and pinks.

CRIMSON GLOW. Compact variety with dazzling

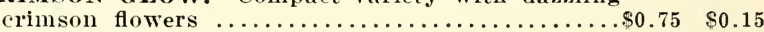

SATIN RosE. Bright carmine............. 60 . $\quad .15$

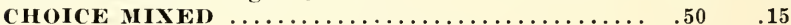

\section{GOURDS}

Grown for their curious fruits, these gourds make interesting covers for walls and trellises.

ASSORTED KINDS

Pkt.

.S0.15

\section{GRASSES}

(Ornamental)

AVENA STERILIS (Animated Oats). Drooping, very

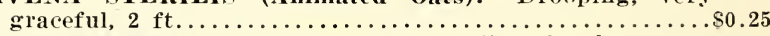
BRIZA MAXIMA (Quaking Grass). Fine for bouquets,

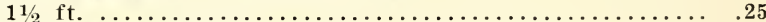

COIX LACRYMAE (Jobs-tears). Seed resembles a tear-

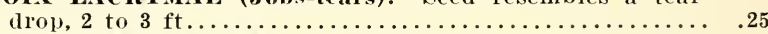

HORDEUM JUBATUM (Squirrel-tail Grass). Bushy pan-

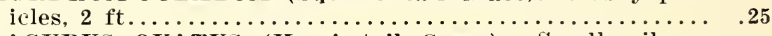

LAGURUS OVATUS (Hare's-tail Grass). Small, silvery

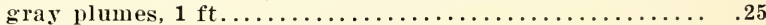

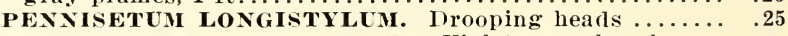

PENNISETUM RUPPELIANCM. Violet - purple plumes,

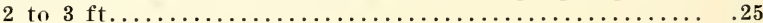

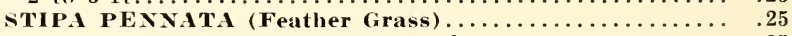

ZEA JAPONICA VARIEGATA. $5 \mathrm{ft} \ldots \ldots \ldots \ldots \ldots \ldots \ldots \ldots . .25$

\section{GREVILLEA}

\section{Silk Oak}

Feril-like foliage. A fine decorative plant for house and

greenlouse easily grown from seed..............\$0.25

\section{GYPSOPHILA ELEGANS \\ Baby Breath}

PARIS MARKET. This strain of Baby Breath is an 


\section{HELIANTHUS}

See Sunflower.

\section{HELICHRYSUM}

Strawflower

Everlasting flower. The dried flowers are highly prized for winter bouquets. $2 \mathrm{ft}$.

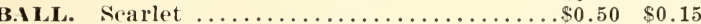

GOLDEN BALL. Golden yellow.............. .50 .15

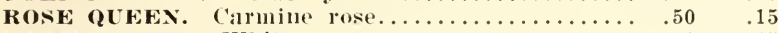

SILVER IBALL. White ..................... 50 . 15

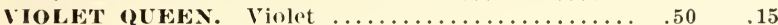

\section{HELIOTROPE}

An old-fashioned favorite because of its fragrance. Suit

able for bedding, boxes, or as a pot plant.........\$0.25

\section{HUNNEMANNIA FUMARIAEFOLIA}

$1 / 40 \%$. I'kt.

Deserves to be more widely grown. liesembles the

California Foppy in foliage and flower, but the

flowers which conn on longer stems last for sey-

eral days as a cut flower.................\$0.50

\section{IPOMOEA}

C.IRIINAL CIMBER. Tlie most beantiful

$$
\text { 1/4 (1). (O). I'kt. }
$$

and distinctive anmul climber intrednced

in many years. Rapid grower with deeply

laciniated foliage literally covered with a

blaze of fiery red flowers from July to

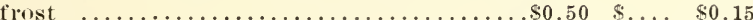

II ENVENi Bris. The large leaves off

this rapid growing climber make a dense

covering for any wall or trellis in a short

time. Large, blue morning glory flowers.

\section{KOCHIA}

\section{Summer Cypress-Firebush}

A rempact busli of delicate green foliage that is arluirable for temporary liedge effects. The whole

busl turus a brilliant searlet in the fall........\$0.40

\section{LARKSPUR}

Showy annuls-splendit for cutting.

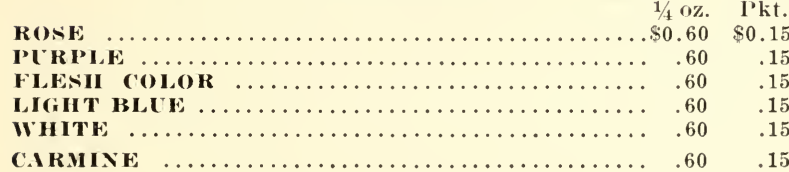

\section{LAVATERA}

\section{Annual Mallow}

Slowy, hardy ammals, useful for massing and cutting.

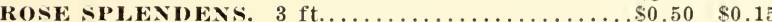

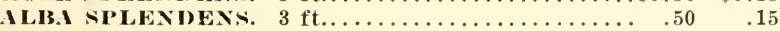

\section{LEPTOSIPHON}

Free flowering ammal, admirably arlapted for edgings and rock work. 3 ill.

CHOICE FRENCH HYHRIDN.

\section{LEPTOSYNE MARITIMA}

I'articularly valuable becanse it blooms early, profusely, and continuously for several months. Golden yellow flowers oll long stems.

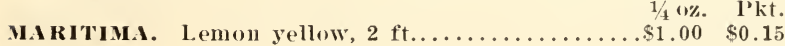

S'TILLMANI. Golden yellow, $2 \mathrm{ft} \ldots \ldots \ldots \ldots \ldots \ldots 1.50 \quad .15$ 


\section{LOBELIA}

COMPACTA CRYSTAL PALACE. This is the leading dwarf variety. Dark blue flowers carried

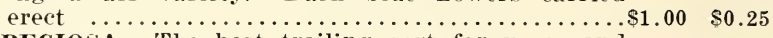

sPECIOSA. The best trailing sort for vases and

baskets. Deep blue........................ $1.00 \quad .25$

\section{LUPINE}

Desirable annual with strong spikes of rose, blue, or white pea-shaped flowers. They are fine for the mixed border and splendid for cutting. They grow luxuriantly in moist soil with partial shade.

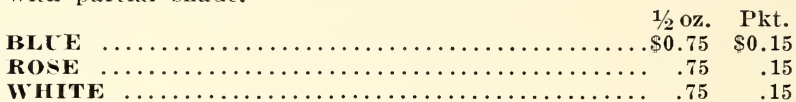

\section{MARIGOLD}

Fistulosa Type

LEMON QUEEN. Very large, double, canary yel-

low flowers. Erect, branching habit, $5 \mathrm{ft}$ tall...\$\$1.00 $\$ 0.15$

ORANGE PRINCE. Like Lemon Queen with flow-

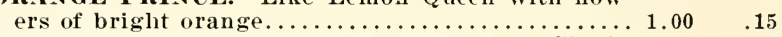

FRENCH TAGETES, LEGION OF HONOR. Single,

bright yellow with maroon center............ $.75 \quad .15$

\section{MARVEL OF PERU}

Four-o-clock

Bushy, half hardy perennial, $2 \mathrm{ft}$.

CHOICE MIXED

\section{MATTHIOLA BICORNIS}

Pkt.

A charming little annual. Very fragrant in the evening.

Purplish lilac flowers, 12 in.....................\$0.15

\section{MESEMBRYANTHEMUM}

An interesting plant for the front of the border or for porch boxes. The fleshy leaves appear as if covered with a thin coating of ice.............\$0.50 \$0.15

\section{MIGNONETTE}

NEW YORK MARKET. This is an extra choice strain of Mignonette developed particularly for the exacting private trade. Large flower spikes of $\operatorname{good}$ substance.......................\$1.00 $\$ 0.25$

MACHET. Long spikes of sweet scented red flow-

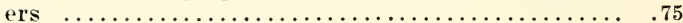

\section{MIMOSA PUDICA}

Sensitive Plant

1/4 oz. Pkt. $\$ 0.50$ 1/4 oz. Pkt. 


\section{NICOTIANA}

\section{Ornamental Tobacco}

This is grown for the large, light green leaves and the fragrant flowers which attract the big night moths. I), best iu a good, rich soil.

AFIYIs, Pure white, sweet scented, $3 \mathrm{ft}$...........

SINDERAE HYBRIDS. Brilliant colors mixed.... .50 .15

\section{NIEREMBERGIA}

GR.ACILIs. Fine for edging or hangiug baskets.

Pretty lilac and white tlowers.............\$0.75 \$0.25

\section{NIGELLA}

Love-in-the-Mist

MISS JEKYLL. A plant with beautiful, finely cut foliage and blue flowers borne close on the stem. It is this effect of flowers nestling in the foliage

that gives it the common name. $11 / 2 \mathrm{ft} \ldots \ldots \ldots \ldots . \$ 0.50$

1/4 oz. Plit. $\$ 0.50 \$ 0.15$

\section{OENOTHERA}

\section{Evening Primrose}

Bright yellow flowers open early in the evening and last

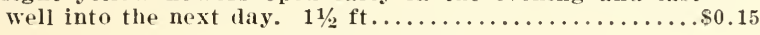

\section{PANSIES}

We have an extra special straiu of large, ruffled pausies grown especially for us....................\$15.00

\section{PETUNIAS}

GIANTS OF CALIFORNIA. These are the large,

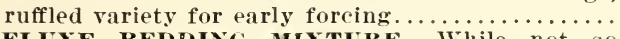

DELUXE BEDDING MIXTURE. While not so

large as the Giants of California they are very

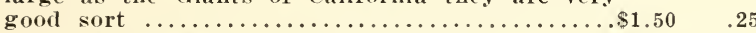

Pride of Portland. Deep rose, friuged............. 1.00

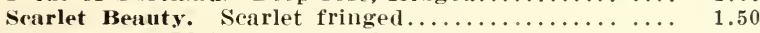

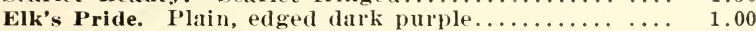

FIMBRIATA MIXED. Large fringed.............. 1.00

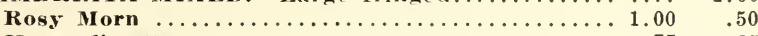

Howard's star ...................... $75 \quad .25$

PENIULA. For porch boxes. Each

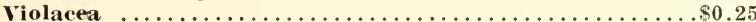

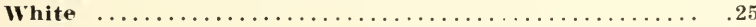

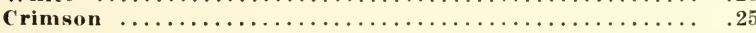

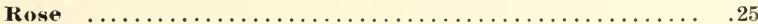

\section{PHLOX DRUMMONDI}

For splendid color lisplay, the f'hlox Drummondi has every desirable quality for beds, edgings, and masses.

\begin{tabular}{|c|c|c|c|}
\hline CRIMSON & . & 0.85 & $\$ 0.25$ \\
\hline FLESH & & .85 & .25 \\
\hline PRIMROSE & $\ldots \ldots \ldots \ldots \ldots$ & .85 & .25 \\
\hline WHITE ... & $\ldots \ldots \ldots \ldots \ldots \ldots \ldots \ldots \ldots \ldots \ldots$ & .85 & .25 \\
\hline SALMON . & 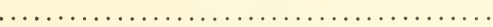 & .85 & .25 \\
\hline
\end{tabular}

\section{POPPIES}

SIIRLEY. Satiny flowers with showy stamens........ s0.15

American Legion. Orange scarlet.................... 15

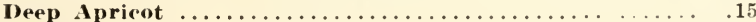

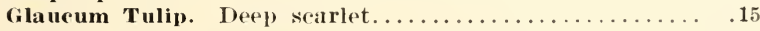

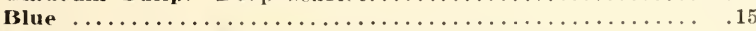

CARNATION FLOWERED. Latrge and donble.

Double American Flag. White with searlet......... .25

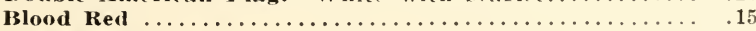

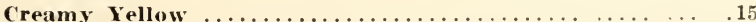

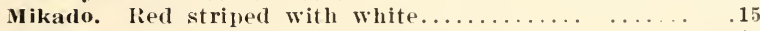

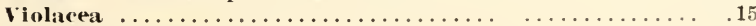

PEONY FLOWEREI).

Black Prince 


\section{PORTULAGA}

Does best in dry warm situations and produces flowers of the most brilliant colors.

$1 / 4 \mathrm{oz}$. Pkt.

.

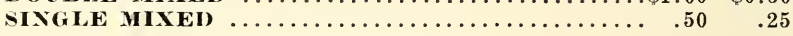

\section{RHODANTHE}

Beautiful, everlasting, much prized for winter bouquets.

\section{RICINUS}

\section{Castor Oil Bean}

Magnificent plants that easily make an 8-10 ft. growth in a season. The large leaves give a subtropical effect.

Oz. Pkt.

the leaves .............................. $\$ 0.35 \$ 0.15$

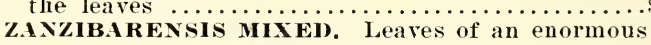

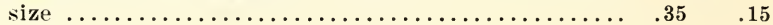

\section{SANVITALIA PROCUMBENS}

This is another splendid edging plant with double yellow

flowers. Blooms profusely all summer. 6 in ..........\$0.20

\section{SALPIGLOSSIS}

\section{Velvet Flower}

A splendid Petunia-shaped flower borne on tall stems that makes them fine for cutting. The colorings are rich with a velvety depth to them that makes one stop and look at them again.

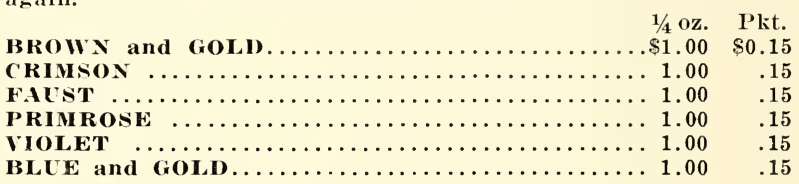

\section{SALVIA}

BON FIRE. A salvia of compact growth, viv-

id scarlet, very popular................\$ \$1.50 \$0.25

SPLENDENS. The old standard bright

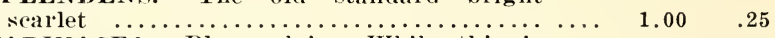

FARINACEA. Blue salvia. While this is

strictly speaking a peremial, it is fre-

quently grown as an annual for cutting

because of its beautiful sky flowers......

\section{SAPONARIA}

splendid for cutting. Sprays are produced in great profusioll. $2 \frac{1}{2} \mathrm{ft}$.

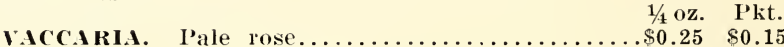

\section{SCABIOSA}

\section{Pincushion Flower}

This should be in every garden for cutting. The stems are long and a profusion of bloom is kept up all summer long if not allowed to go to seed.

\begin{tabular}{|c|c|c|}
\hline U 131 & $\begin{array}{l}1 / 4 \mathrm{oz} . \\
\$ 0.50\end{array}$ & $\begin{array}{l}\text { P'kt. } \\
\$ 0.15\end{array}$ \\
\hline WLPHCR YELLOW & .50 & .15 \\
\hline LESH PINK & .50 & .15 \\
\hline & .50 & .15 \\
\hline G OI & .50 & .15 \\
\hline ACH BLOSAOM & .50 & .15 \\
\hline
\end{tabular}

\section{SCHIZANTHUS}

A dainty annual that is often used as a pot plant. The blooms are gaily colored, looking like tiny butterflies poised. The foliage is finely eut and attractive.

1,160z. Pkt $\$ 2.00 \$ 0.50$ 


\section{STATICE}

This has become an indispensible plant for winter bouquets both for the home and for the commercial grower. The flower. heads that mature in the fall keep their color pertectly and their fine branching habit makes them ideal for bondnet arrangements.

1/10\%. Plit.

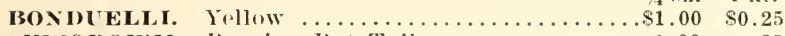

stwOROWII. Iinssian liat Tail............ $1.00 \quad .25$

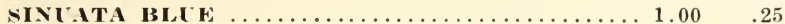

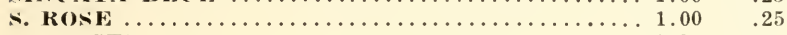

s. WHITE ......................... $1.00 \quad .25$

\section{SILENE PENDULA}

compact, dwalf, valuable for elgings, 4 in.

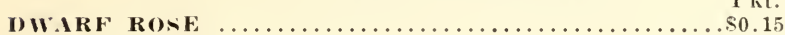

DWIRE WUITE $\ldots \ldots \ldots \ldots \ldots \ldots \ldots \ldots \ldots \ldots \ldots \ldots \ldots \ldots \ldots, 15$

\section{STOCKS}

Annnal stocks for greenhouse culture or in the outdoor garden are equally good. They do best in a cool, moist sitnation. Our strain runs very donble, and the large stalks of rlovescented flower's make a refreshing bonquet for any room.

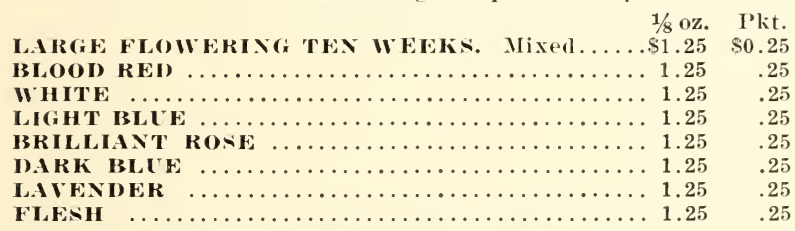

GIANT IMPERIAL O IMPROVED BINMARK.

An especially finc stratin showing searcely any singles.

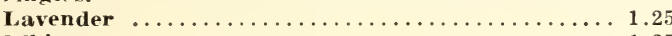

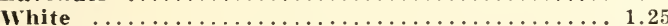

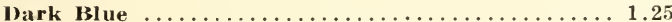

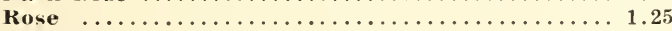

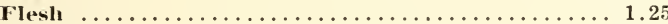

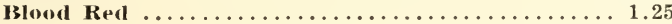

Plit. .25

\section{SUNFLOWER}

\section{Helianthus}

CICIMERIFOIIC. Small, single rich yellow

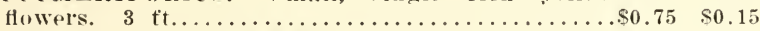

DOTBLE CALIFORNiAN. Large, domble vellow flowers. $5 \mathrm{ft} \ldots \ldots \ldots \ldots \ldots \ldots \ldots \ldots \ldots \ldots \ldots \ldots . .50$

\section{SPENCER SWEET PEAS}

IPPLE BLosion. Bright rose stamdard with wings of rose-carmine..........\$ $\$ .50 \quad \$ 1.50 \$ \$ 5.00$

As'T.A OrIN. Suffused lavender.......... .50 $1.50 \quad 5.00$

BLCE PICOTEE. Pure white with narrow elge of violet..................... $50 \quad 1.50 \quad 5.00$

COCNTESS SPENCER. Bright clear pink.

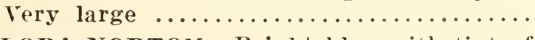

FLORA NORTON. Bright blue with tint of purple

IERCULES. Lovely rich pink of giant form and substance $\ldots \ldots \ldots \ldots \ldots \ldots \ldots \ldots \ldots \ldots \ldots \ldots \ldots \ldots \ldots \ldots$

ILLCMINATOR. Bright salmon tinged with orange

IIIG EDWARD. Brilliant erimson searlet. KING WhITE. Best white spencer. Wary

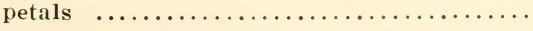

MRS. HUGH ICIKsox. Puff, apriont, and rose $\ldots \ldots \ldots \ldots \ldots \ldots \ldots \ldots \ldots \ldots \ldots$.

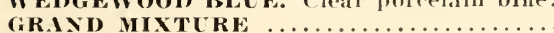




\section{SWEET PEAS-Continued \\ WINTER FLOWERING VARIETIES}

Oz. Pkt.

BLCE BIRD. A charming shade of blue........\$1.00 $\$ 0.25$

BURPEE's ORA NGE. Clear pure orange........ 1.00 .25

GLITTERs. Fiery orange suffused with deep

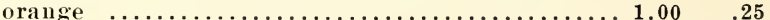

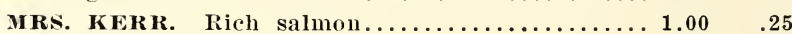

ROAE QUEEN. Fine, light rose, pink.......... $1.00 \quad .25$

WHITE STAR. Large, pure white.......... $1.00 \quad .25$

ZVOLENEKS ROSE. One of the best deep pink

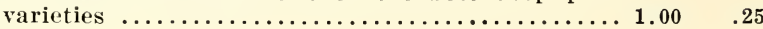

\section{THUNBERGIA}

Rapid growing annual climber or creeper with pretty

buff, white, and orange flowers with a dark eye.......\$0.15

\section{TORENIA}

This is the one annual that will bloom profusely all summer in the shade. For the edge of the shady border they are perfect with their small, velvety blue flowers.

FOURNIERI GRANDIFLORA. Light blue, yellow throat. $\$ 0.25$

\section{VERBENA HYBRIDA GRANDIFLORA}

A magnificent new strain of Verbenas, robust, compact habit and free blooming. The trusses of flowers are immense, the individual florets measuring an inch across.

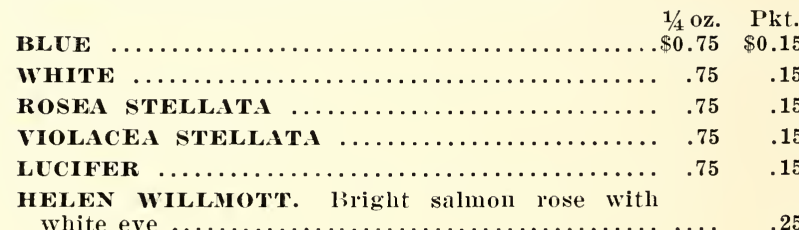

\section{VINCA}

ALBA PURA. Pure white $\ldots \ldots \ldots \ldots \ldots \ldots \ldots \ldots \ldots \$ 0.75 \quad \$ 0.15$

ALBA ROSEA. White with rose center.........

\section{WALLFLOWER}

\section{Annual Paris}

This extra early strain, if started early, will bloom the same season. Excellent for forcing.

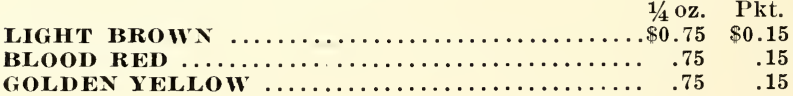

\section{ZINNIAS}

Dahlia Flowered

Our Zinnia seed comes direct from the originator of the Dahlis Flowered Zinuias. The percentage that comes true to form is high. For a showy garden flower notling can be better.

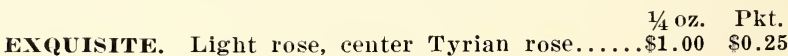

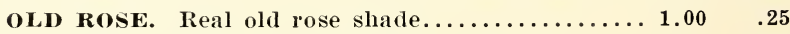

GOLDEN STATE. Rich Cadmium yellow........ $1.00 \quad .25$

ORIOLE. Most beautiful orange and gold bicolor. . $1.00 \quad .25$

PURPLE PRINCE. Fine, deep rhodanthe purple.. $1.00 \quad .25$

CRIMSON MONARCH. Red.............. 


\section{GERMAN PEAT MOSS}

\section{IN BALES}

Imported from Northern Germany

It comes packed in standard size bales measuring $20 x$ $22 \times 40$ inches or approximately $12 \mathrm{cu}$. ft. Especially recommended for mulching around Trees, Evergreens, Shrubs, ete., in the preparation of new Lawns, the repairing of old ones-and for propagating.

We carry a stock in our warehouse for immediate delivery, and also offer a special price inducement for advauce orders of 10 bales or over, delivered direct from carlot arrivals at our station-Rocky River, Ohio.

We will be pleased to quote you on your requirements.

Approximate Areas Covered by Ground Peat Moss:

1 bale will cover approximately. $\overbrace{250}^{\text {squart Feet- }}-80$

6 bales will cover approximately .. $1500 \quad 750 \quad 450$

13 bales will cover approximately . $3250 \quad 975 \quad 1000$

51 bales will cover approximately ..12750 $6375 \quad 4000$

150 bales will cover approximately ..37500 $18750 \quad 12000$

\section{LAWN SEED MIXTURES}

\section{LAWN GRASS SEED}

GOOITIRF MIXTek. We can say with assurance that it is impossible to make a better lawn mixture than this one. We have carefully tried ont many different formulas before we worked out the most desirable analysis for this mixture.

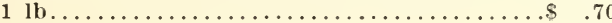

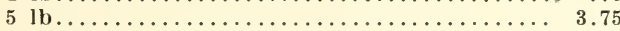

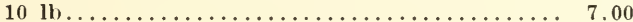

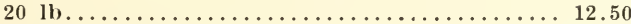

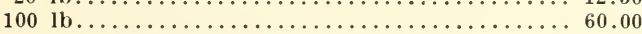

SH.IDY PLACE MITCRE. Will grow in any shady location if it is possible for grass to grow there. We have spent a lot of time and study on grasses. Our experience in producing good lawns is at your command.

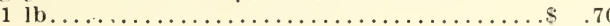
$5 \mathrm{lb} \ldots \ldots . .3 .40$

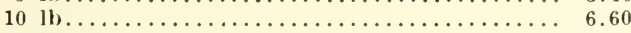

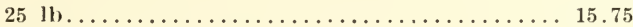

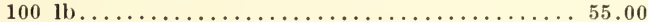

\section{Special Mixtures for Hay and Permanent Pasture}

These mixtures include the most nutritive and productive grasses suitable for laying dowu light, medium and heary soils to permanent grass. State nature of soil when ordering... \$12.00 $\$ 45.00$

\section{FINE GRASS SEEDS IN QUANTITY}

Prices on these seeds open, quotation sent upon request.

FANCY KENTUCKY BLCE GRASS. Our stock of Blue Grass is extra fine. Sow 75 to 85 lbs. per acre on lawns.

CANADIAN BLUE GRAss. Makes an ideal pasture for cattle. Very good for sowing on embankments. Sow same amount as Kentucky Blue.

CRESTEI DOGTII. Fine for both pasture and lawn. Sow 80 to 100 lbs. to acre.

CHEWING'S NEW ZEALAND FEsCLE. Especially recommended for putting green and lawns.

FINE LEAVED FEsCUE. Especially valuable for dry soils. Sow 70 to 85 lbs. per acre.

RED FEsCUE. Valuable for puttiug greens, also for sowing on sandy soil and in shaded places. 


\section{GRASSES-Continued}

ORCHARD GRASs. For early pasture this is very desirable, also for sowing in shady places.

ENGLISH OR PERENNIAL RYE GRASS. This makes the quickest return in growth of any grass. Is deep rooted and quickly established. 100 to $120 \mathrm{lbs}$. per acre.

ITALIAN RYE GRASS. Very desirable for pasture, comes to maturity the first season. $100 \mathrm{lbs}$. per acre.

WOOD MEAIOW. The best grass for sowing under trees where a lawn is desired. 75 to $100 \mathrm{lbs}$. per acre.

WHITE DUTCH CLOVER. Splendid for sowing among grass on lawns and other places where a thick, quick growth is desired.

\section{FARM AND FIELD SEEDS}

\section{Subject to Market Prices} BEANS

SOJA. Mammoth yellow.

\section{BUCKWHEAT}

Sow 1 bushel to the acre.

JAPANESE. Earliest and very productive. (Bushel $48 \mathrm{lbs}$.)

\section{FIELD CORN}

8 quarts will sow 1 acre in hills.

3 bushels will sow one acre broadeast.

Prices will be cheerfully quoted on Flint or Dent varieties wanted. Also on Ensilage and Fodder Corn.

\section{MILLET}

Sow 1 bushel to the acre.

HCNGARIAN. A fine summer forage crop. GOLDEN MILLET. A very heavy cropper. JAPANESE. Tall grower.

\section{MANGEL SEED}

See Specialty Page.

\section{PEAS}

Sow 2-3 bushels in drills to the acre.

CANADA Ficho. Valuable for cattle feerling.

\section{RAPE}

Sow $10 \mathrm{lbs}$. to the acre broadcast.

Sow 4 lbs. to the acre in drills.

DWARF ESSEx. Its fattening properties are said to be better than Clover.

\section{RYE}

Sow 2 bushels to the acre.

SPRING. An excellent catch crop.

MAMMOTH WINTER. Heary heading. Sow in August and September.

\section{VETCHES or TARES}

Sow 2 bushels to the acre.

SPRING. Valuable for green manuring. Produces good crops on poor, sandy soils.

WIXTER. Valuable for green manuring. Produces good crops on poor, sandy soils.

MARQUIS. Beardless.

WHEAT (Spring)

Sow 2 bushels to the acre.

WHEAT (Winter)

\section{BEST VARIETIES.}

\section{OATS}

Our BUMPER CROP strain is a splendid crop produeing oat. The straw is strong and tall growing, the grain plump and full. Those who have tried it ask for the same strain every year.

1 to 100 bushels. ...................... $\$ 2.00$

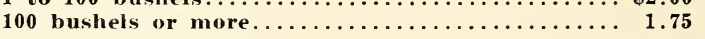




\section{CLOVERS}

I'rices subject to change.

ALFALFA or LCCERNE (Medieago Sativa). Valuable as a forage crop, produces enormous crops. Northern grown.

ILFALFA GRIMI. Hardier and more productive than the ordinary Alfalfa. Thrives well on hard pan soils, and is better suited to wet soils than other kinds.

ILSIKE CLOVER (Trifolium Hybridum). Very hardy, resists cold and wet.

CRIMSON Or SCARLET CLOVER (Trifolium Incarnatum) An annual variety of rapid growth valuable as a cover crop or for green manuring. Sow $20 \mathrm{lbs}$. to the arre.

MEDICM RED CLOVER (Trifolium Pratense). The common red Clover and the most valuable.

MAMMOTH RED CLOVER or PEA VINE. (Grows taller and lasts longer than the Medium Red.

WHITE CLOVER (Trifolium repens). The best variety for lawn mixtures.

SWEET CLOVER, BOKHARA (Melilotus Alba). U'sed oll poor, light soils when other Clovers do not take well.

\section{DAHLIAS}

The Finest Varieties in All Classes.

We are distributors for W. H. Waite, originator of Jersey Beauty and many other fine Dahlias and an acknowledged leader in the Dahlia field. A catalogue devoted to Dahlias will be sent immediately upon request.

\section{GLADIOLI}

CHOICE NAMED VARIETIES

ALTAIR. Warm saffron-salmon primulina.

Only "glad" of this color................ \$0.10 $\$ 1.00 \quad \$ 7.00$

CHATEAU TIIERRY. Brilliant scarlet with large showy yellow blotch. Brightest spot in the garden..............................

DOROTHY McKIBBEN. New, ruffled pink,
pure apple blossom, splendid cut flower,

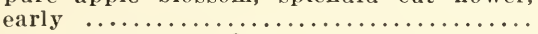

E. J. SHAYLOR. One of the deepest rose pinks, large flower, much ruftled...........

HERADA. Pure mauve, no other "glad" of

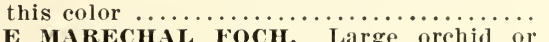
LE MARECHAL FOCH. Large orchid or lavender pink ...........................

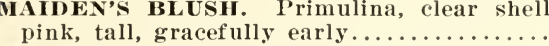

MARY PICKFORI. A soft creamy white in-

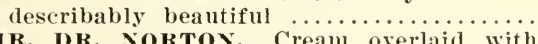

IR. DR. NoRTon. Cream overlaid with pink. A most beautiful color..............

MYRA. Primulina giant, ruffled, deep sal-

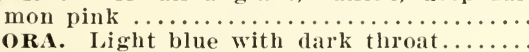

NORA. Light blue with dark throat........
ORANGE GLORY. Ruffled, large open flow-

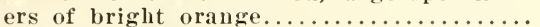

PRIDE OF LANCASTER. Brilliant orange,

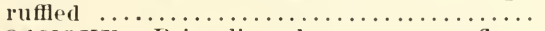

ROANOKE. Primulina, large creamy flow-

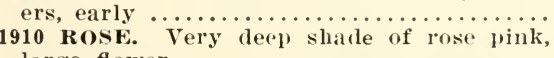

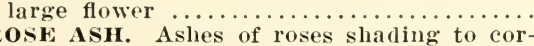

ROSE ASH. Ashes of roses shading to corinthian red .........................

CARLET PRINCEPS. Bright cherry red,
wide flowers $\ldots \ldots \ldots \ldots \ldots \ldots \ldots \ldots \ldots \ldots \ldots \ldots \ldots \ldots$

SCARLET WONDER. Largest "glad" in existence, large glowing scarlet with trace

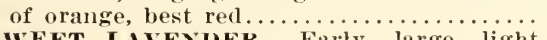

SWEET LAVENDER. Early, large, light

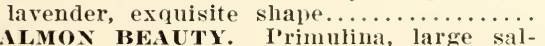

SILMON BEAUTY. I'rimulina, large sal-

IOLET GLORY. Ruffled, massive, rich deep violet 


\section{MISCELLANEOUS BULBS and ROOTS}

\section{ACHIMENES}

Free flowering, tender perennials for greenhouse decoration during summer. They thrive in moist warm temperature shaded from the sun.

CHOICE MIXED VARIETIES

Doz. 100

\section{AMARYLLIS}

Giant Hybrids

Our Amaryllis are grown for us by an acknowledged leader in this field. Colors cover a wide range-from white to crimson. Each Doz. 100

LARGE BULBS IN CHOICE MIXTURE....\$0.75 $\$ 8.50 \quad \$ 68.00$

\section{TUBEROUS ROOTED BEGONIAS}

These are gayly beautiful flowers that will bloom in the shade. For the dark corner that has been a problem, try these and you will be more than happy over the effect. They come in

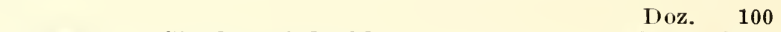

CRIMSON. Single and double..............\$3.50 $\$ 25.00$

PIX K. Single and double.................. $3.50 \quad 25.00$

SCARLET. Single and double.............. $3.50 \quad 25.00$

WHITE. Single and double.................... $3.50 \quad 25.00$

YELLOW. Single and double................. $3.50 \quad 25.00$

S.M.MON. Single and double............... $3.50 \quad 25.00$

\section{CALADIUM ESCULENTUM}

Elephant's Ear

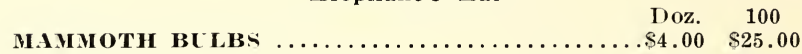

\section{GALADIUM}

Fancy Leaved

$\$ 4.00 \$ 25.00$

CHOICE VARIETIES

\section{CALLA ELLIOTTIANA}

Each Doz. 100

YELLOW CALIA

$\begin{array}{lll}\$ 0.60 & \$ 6.00 & \$ 45.00\end{array}$

\section{CANNAS}

We carry in stock ten varieties of the best kinds. We grow a number of the more popular sorts in four-inch pots for delivery during May and June. Place your order early.

\section{DICENTRA SPECTABILIS}

\section{Bleeding Heart}

This plant is a universal garden favorite

$$
\text { Each Doz. } 100
$$

with its delicate foliage and its long pen-

dulous branches of heart shaped flowers.

The Bleeding Heart does not object to a

little shade, and likes to be left alone

without being disturbed after it is once

planterl. Strong 2-year-old roots........\$1.00 $\$ \$ 7.50 \quad \$ 60.00$

\section{GLOXINIAS}

Charming summer flowering bulb for the conservatory or window garden.

FINE MIXTCRE. Blue, pink, red, purple and

white are colors included in this mixture...... \$4.00 $\$ 30.00$

\section{HYACINTHUS CANDICANS}

\section{Summer Hyacinth}

This is a splendid summer flowering bulb, contrasting well with the Gladiolus. The stalks are four to five feet in height and bear many white, bell-shaped flowers. They are most effective when planted in small clumps of from five to ten bulbs. The bulbs should be planted about eight inclies apart and five inches deep. 


\section{MONTBRETIAS}

Iontbretias are delicate miniatures of gladiolus. They are fast gaining popularity as cut flowers and make charming arrangements in bowls and vases. The stems are slender amcl wiry, the flowers dainty in texture and coloring. They are a splendid addition to the pereminal border where they should be planted in large clumps. $\$ 0.90 \$ 6.00$

\section{TUBEROSES}

Plant tuberoses in the garden in May in rich soil in a smmy location and they will bloom in September. If early flowers are wanted, bulbs shonld be started in a hotbed in March or April and set out in the garden after danger of frost is past in late May or June. Mammoth or Jumbo bulbs sure to bloom. $\begin{array}{lll}110 \% & 100\end{array}$

DWARF DOCBIE PEARL.............. $\$ 1.25 \quad \$ 8.50$

\section{ZEPHYRANTHES}

Zephyr Flower or Fairy Lily

Beantiful, dwarf bulbous plant, very effective for

massing, fiue for pot cult ure..............\$1.75 \$12.00

\section{LILY-OF-THE-VALLEY}

This charming flower is so well known that it needs no description. It does well in partial shade and rather moist soil. We have large chumps, which, if planted early, will bloom this May.

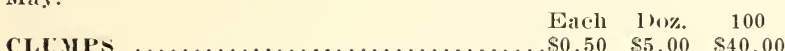

\section{HARDY GARDEN LILIES}

You will want some of these stately lilies of rale fragrance in your perennial garden. Most lilies will do well in partial sharle.

ACRATUM. Chinese Gold Band, Lily, a wide band of yellow through each white petal.

Very large flowers, tall growing.......... $\$ 0.50 \quad \$ 5.00 \quad \$ 38.00$

CANADENSE. Bell shaped blossoms in rich orange-red. Ten to fifteen blooms on a

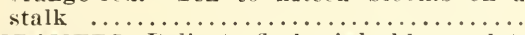

KRAMERI. Delicate flesli pink, blooms late

KEGALE. Recently introduced from China and proving to be one of onr best lilies. Flowers a large white trmmet washed with pink and yellow at the base........

SPECIOSUM ALBUM. Pure white, waxy, reflexed petals. Blooms August and Sep-

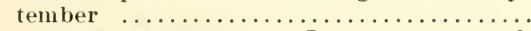

SPECIOSUI HENRY. Large, orange-yel-

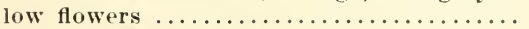

SPECIOSUM RCBRUM. Bright pink, reflexed petals $\ldots \ldots \ldots \ldots \ldots \ldots \ldots \ldots \ldots \ldots \ldots \ldots . \ldots \ldots$
TIGRINIUM. Tiger Lily, deep yellow with brown spots ..................... . 30 $3.00 \quad 23.00$

\section{LILY-OF-THE-VALLEY PIPS \\ (Cold storage)}

Will bloom in 21 days after planting.

We make a specialty of Lily-of-the-Valley: the grade we handle is the very best that can be procured. I'lace your orders now, for present and future deliveries. 


\section{GREENHOUSE PLANTS}

\section{For Delivery During the Summer and Autumn}

\section{BEGONIA.}

Gloire de Lorraine. $2 \frac{1}{4}$ in. and 3 in. pots.......\$40.00-\$50.00

Glory of Cincinnati. $2 \frac{1}{4}$ in. and 3 in. pots...... 50.00- 75.00

Melior. $21 / 4$ in. and 3 in. pots................ 50.00- 75.00

Irs. Peterson. $2 \frac{1}{4}$ in. and 3 in. pots.............5 50.00-75.00

BOUVARDIA. Pink and white, 21/4 in. pots......\$4.00 $\$ 25.00$ BUDDLEIA ASIATICA. 3 in. pots.............. $4.50 \quad 35.00$

CALCEOLARIA HYBRIDA. 21/4 in. pots........ 4.00 30.00

Calceolaria Lymani. Cinnamon red, 21/4 in. pots. $8.00 \quad 60.00$

Calceolaria Medfordi. Velvety maroon, $2 \frac{1}{4}$ in.

pots .............................. $8.00 \quad 60.00$

Calceolaria, Stewarti. Chrome yellow, $2 \frac{1 / 4}{4}$ in.

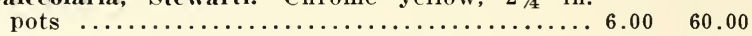

Calceolaria, Pink Beauty. 21/4 in. pots........ $8.00 \quad 60.00$

CINERARIA HYBRIDA. $21 / 4$ in. pots.............. $3.00 \quad 20.00$

CINERARIA STELLATA. $21 / 4$ in. pots............

ERLANGEA TOMENTOSA. 21/4 in. pots....... 4.00 30.00

CXCLAMEN. (Giant Flowering.) Best strain.

Pure White, 3 in. pots..................... 30.00

White with Pink Eye. 3 in pots................ 30.00

Pink. 3 in. pots........................... 30.00

Glory of Wandsbek. 3 ir. pots................... 35.00

Salmon. 3 in, pots........................... 30.00

Red. 3 in. pots.............................. 30.00

EUPHORBIA JACQUINAEFLORA. $2 \frac{1}{2} 2$ in. pots..... 30.00

IIARGUERITES.

White. 3 in. pots $\ldots \ldots \ldots \ldots \ldots \ldots \ldots \ldots \ldots \ldots \ldots \ldots, 25.00$

Boston Yellow. 3 in. pots......................... 25.00

POINSETTIAs. True oak-leaved variety, 3 in.

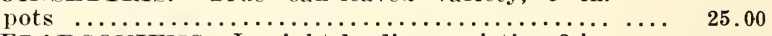

PELARGONIUMS. In eight leading varieties, 3 in.

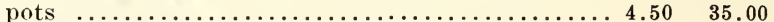

PRIMULA MALACoIDEs. In separate colors, $2 \frac{1}{4}$

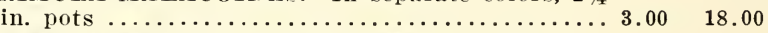

PRIMULA MALACOIDES LELANDI. Flowers are

lilac-pink with yellow center measuring 1-11/2

across, produced on long, stiff stems, $2 \frac{1}{4}$ in. pots $3.00 \quad 18.00$

PRIMULA OBCONICA. In separate colors, $2 \frac{1}{4}$ in.

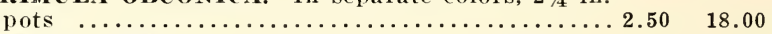

SMALL FERNA. In variety, for Fern dishes, $21 \frac{2}{2}$

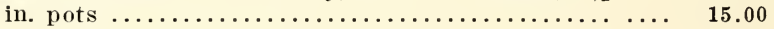

\section{BEDDING PLANTS}

\section{For May Delivery}

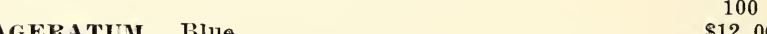

. $\$ 12.00$

BEGONIA ERFORDI. 3 in. pots.................... 25.00

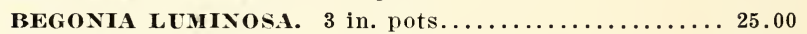

BEGONIA VERNON. 3 in. pots.................... 25.00

COLEUs. In variety........................... 8.00

GERANIUM.

Alphonse Ricard. Scarlet, 4 in, pots.............. 35.00

Glory of Poitevine. Pink, 4 in. pots.................. 35.00

S. A. Nutt. Red, 4 in. pots......................... 35.00

Ime. Buchner. White, 4 in. pots............... 35.00

HELIOTROPE. Sweet-scented varieties, light and dark

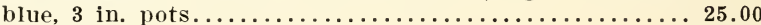

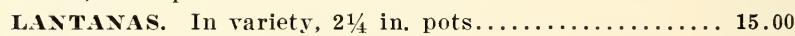

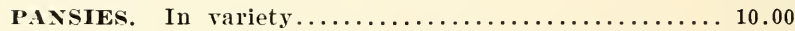

PETUNIA. Rosy Morn. 21/2 ill. pots............... 18.00

\section{VERBENAS.}

Blue. $2 \frac{1}{2}$ in. pots................................. 18.00

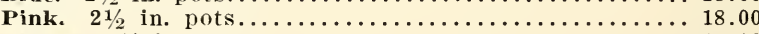

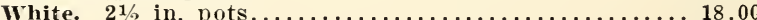

We are in a position to supply all kinds of rooted cuttings, such as Chrysanthemums, Carnations, etc., the stock being extra fine quality. Prices quoted on application. 


\section{NURSERY STOGK}

Thru our connections with several first-class Nurseries we can supply EXTRA FINE STOCK of SHRCIBSTREES-EVERGREENS and PERENNIALs at the regular market prices and assure satlsfaction.

For those who desire SPECIMEN STOCK the Attwood Co. will personally select same to conform with the eustomer's needs and guarantee satisfaction.

With our contacts we are in a position to secure the unusual in plant life and will be most pleased to secure for our customers uncommon and very searce Horticultural subjects.

\section{HYBRID TEA or EVERBLOOMING ROSES}

Extra strong field-grown plants, $\$ 1$ each, $\$ 10$ per dozen.

April delivery.

BETTY. Extra large flowers, full and fragrant, of a peculiar shade of coppery rose, overspread with golden yellow.

CHATEAU DE CLOS VOCGEOT. An indispensable Rose in any garden by reason of its deep, soft, velvety scarlet flowers of the utmost richness and most notable fragrance.

COLUMBIA. The lively pink buds and blooms do not fade as they mature. Nearly thornless stems, freely produced on strong plants.

DUCHESS OF WELLINGTON. Vigorous and free-flowering Rose. Its buds are slim and elegant, saffron-yellow, and opening to a loose and informal flower of great sweetness.

FRANCIS sCOTT KEY. Its pleasing crimson buds quickly open into a very double flower of immense size.

GENERAL MaciRTHUR. Large, full, and well-shaped flowers of velvety scarlet.

GEORGE C. WAUD. Fine and fragrant globular flowers of bright and different red-crimson on a vigorous plant that persists in blooming all summer.

GRUSS AN TEPLITZ. The one Rose that blooms all summer and autumn, defying drought and hot sun. Its glowing crimson flowers are in clusters.

HARRY KIRK. Probably the most dependable in its color, which is the much-desired clear yellow.

H. V. МАснIN. Very large flowers of the much-admired scarlet-crimson color, on sturdy and productive plants.

JONKHEER J. L. MOCK. Cherry-red and silvery pink in an immense bud and flower that looks like an intensified La France.

KILLARNEY QUEEN. Remarkable for its very long and lovely pink buds, freely produced on a vigorous plant.

LAIY ALICE STANIEY. Deep coral-rose on the outside of the broad petals, pale flesh on the inside, with well-shaped buds which develop into fragrant blooms.

LADY ASHTOWN. Pale crimson-pink, shading to golden yellow at the base of the petals.

Los ANGELEs. Awarded world's highest Rose honor at Paris in 1918. Color indescribable-flame-pink, apricot, salmon, gold, mingled in an informal flower of notable fragrance; buds exquisite.

MME. BUTTERFIY. Flowers are a brilliant pink, suffused apricot and gold.

MME. CAROLINE TESTOUT. Broad petals of satiny rose make up the large, rounded flower, shaded darker at the center and lighter at the edges.

MME. EDOUARD IERRIOT. Its coral-red buds develop into flowers of the same hue, shaded yellow to scarlet.

MME. JULEs BOUCHE. A most dependable white Rose, its lovely buds being tinted and flushed pink at times.

MRS. AARON WARD. A Rose of pleasing surprises because of its color variations, all based on its normal, deep Indianyellow hue.

MRS. AMBROSE RICARDO. Large blooms of fine substance, deep yellow overlaid witl a lighter color and suffused in pink. 


\section{WATER PLANTS}

\section{WATER LILIES}

\section{General List of Hardy Water Lilies}

The stock offered is very fine-grown by Rose Brothers, Water Lily specialists, of Independence, Ohio.

Each

INIRA. Canary yellow, changing to red..........\$4.00

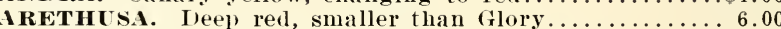
ICRORA. Iosy yellow, changing to yellow red....... 3.00 CHROMATELLA. Rich yellow ................. CHRYSANTHA. Cream vellow, changing to orange ver-

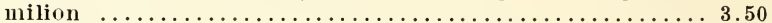
COMA NCHE. Rich apricot, changing to coppery bronze. 5.50 EUGENIA DELANI). Rose with white tip.......... 2.00 FORMOSA. Opens light pink, deepens with age.......8.50

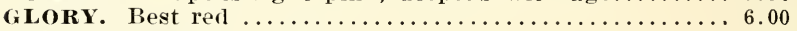

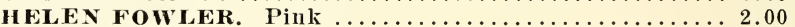

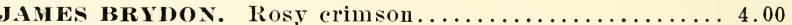

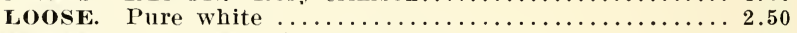

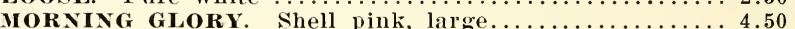

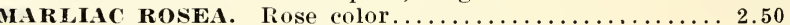
IASANIELLO. Rose pink with white sepals......... 4.00 PINIK OPAL. Deep rich pink................. 3.00 PACL HARIOT. Yellow, changing to apricot........ 5.00

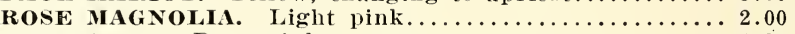

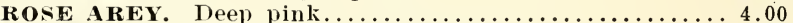
SIOCX. Rich brassy yellow, shading red............ 4.00 SPLENDEDA. Deep pink with white sepals.......... 8.50

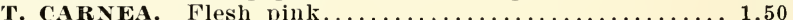

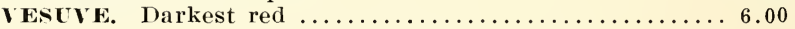

\section{General List of Tropical Lilies}

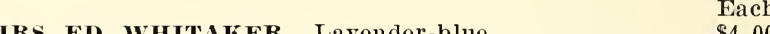
IIRS. WHITAKER. Darker and larger, dark foliage.... 5.00 PINK ZANz. Rose pink.................... 3.00 PURPLE ZANZ. True purple.................. 5.00 PURPLE ZANZ ............................. 4.00 DAUBEN. Light blue viviparous................ 2.00 PANAMA-PACIFIC. Redish purple viviparous....... 4.00 AUgUST KOCH. Purplish lilas viviparous............... 3.00 PENNSYLVANIA. Deep blue $\ldots \ldots \ldots \ldots \ldots \ldots \ldots \ldots \ldots .50$ IIRS. GEO. H. PRING. White................ 4.00 MRS. C. W. WARD. Rich rose pink................ 3.00 GENERAL PERSHING, Large pink $\ldots \ldots \ldots \ldots 6.60$

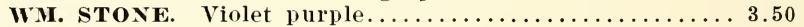

\section{OXYGENATING PLANTS FOR POOLS OR AQUARIUMS}

ANACHARIS. Dark green foliage......3 buncles $\$ 1.00 \$ 3.00$ PARROT FEATIIER ….......... 2.50 DUCK WEED. Small floating plant.

.50 $\ldots \ldots \ldots \ldots \ldots \ldots \ldots \ldots$ Large portion-Fach .75 SiLVINIA. Floating plant...Large portion-Each .75 SHELL FLOWER. Iosettes of bluish leaves. . $\$ 0.40 \mathrm{each}$

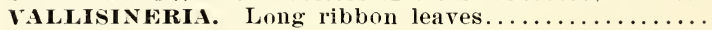
W. TER HYACINTH. Lavender flowers...... for $\$ 0.75$

\section{SHALLOW WATER PLANTS}

C.T T. IL. Hardy ................... for $\$ 0.75 \$ 2.50$ VARIEGATED SWEETELAG. Hardy....... for $1.50 \quad 4.00$ GREEN SWEETFLAG. Hardy........... for $.75 \quad 3.00$ PICKEREL RUSH. Hardy. Blue flower....2 for $.75 \quad 3.50$ GIAN'T ARROWHEAD. Hardy. White flower.3 for $1.50 \quad 3.50$ FIOATING HEART. Hardy. Yellow flower..3 for $.75 \quad 2.50$ MARSH MARIGOLD. Hardy. Buttercup-

like flower $\ldots \ldots \ldots \ldots \ldots \ldots \ldots \ldots \ldots \ldots \ldots \ldots$ for $1.50 \quad 4.00$ P.IPYRUS or EGYPTIAN PiPER PLANT . . 3 for $1.50 \quad 3.50$ JAPANESE TARO. Green leaf...........\$1.00 each $\ldots .$. IMPERIAL TARO. Dark velvety leaves...... 1.50 each $\ldots$. CREEPING WATER HYACINTH. Purple

flower. Very scarce................. for $\$ 1.50$ VELVETLEAF. Straw colored flower.......2 for 1.50 EGYPTIAN LotTUs. Speciosum. Large pink........ 2.50 EGYPTIAN Lo'TUS. Pekinese. Double pink........... 6.00 MMERCAN Lot'US. Lutea. Vellow............. 2.50 


\section{MARSH PLANTS}

$100 z$.

TRIE SWAMI FORGE'T-ME-NO'T. Hardy . . 3 for $\$ 1.50 \$ 3.50$ YELLOW SWIMP IRIS. Hardy......... for $1.50 \quad 3.50$ BLUE NWAMP IRIS. Hardy........... for $1.50 \quad 3.50$

\section{COLLECTION OF HARDY LILIES}

CHROMATELLA. Yellow ........ T

SIOUX. Changeable ............. This collection for $\$ 6.00$

PINK OPAL. Deep pink.........

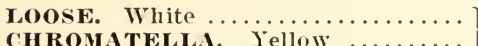

CHROMATELLA. Tellow .........

MORNING GLORY. Shell pink...... This rollertion for $\$ 10.00$

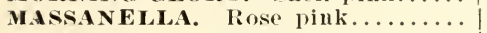

T. CARNEA. Flesh pink..........

\section{COLLECTION OF TROPICAL LILIES}

MRA. PRING. White...........

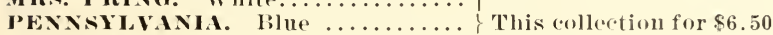

PINIX ZANZ. Pink..............

MRA. PRING. White...........

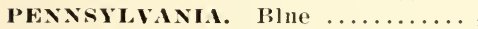

JEPITER. Purple .............. This enllection for $\$ 10.00$

ICGUS'T KOCH. Purplo-lilac.......

D.ICBEN. Jight blue...........

\section{HARDY ALPINES OR ROCK PLANTS}

Extra strong Plants

Delightful little plants suitable for crevices in parements. or steus, and relied upon to furnish the more elaborate rock gardens. Because of their hardiness and dwarf growth they are also very satisfactory for edging flower beds and borders.

IRABIS ALIINA NANA COMPACTA. Dwarfest variety . $\$ 5.00$

ARENARIA MONTANA. Creeping variety forming mounds of green, covered in early spring with large white

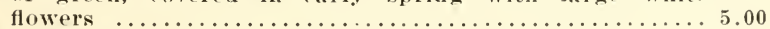

ATIBRETIA DELTOIDEA GRAECA. Lilac-l)lue....... 7.00

AUBRIETIA DELTOIIEA PIRPUREA. Shests of rich

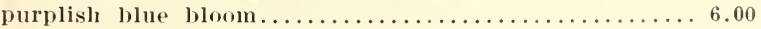

C.IMPANULA ROTUNIDIOLIA. Deliate blue. 8 to 10

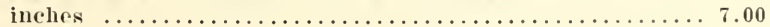

DIANTHUS ALPINIs. Lovely Alpine I'ink that thrives in partial shade. l'rofuse bright rose blooms in pro-

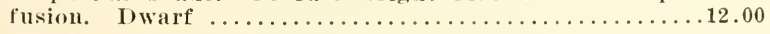

FRINUS ALPINCS. Purple flowers in racemes. 6 inches. 7.00

GYPSOPHIL REPENS. Trailiug plant for rockery or wall-garden. Delicate small flowers in July and August. 5.00

IBERIS SEMPERVIRENA. Pure white flowers in June. Glaucous blue foliage. 6 iuclues................ 5.00

LEONTOPOIIUM IIPINUM (Edelweiss). Woolly flowerleads on 6-incli stalks lise from a loose tuft of narrow

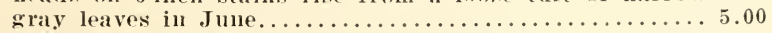

LINARIA ALPINA. One of the lovoliest rock plants, boaling a profusion of rich violet flowers witl orange throat, like a miniature snapdragon. Hlomms continuously from frost to frost. 3 inclies................. 7.00

LINARIA IIPINA ROSEA. Like the above, but bearing a profusion of pale pink blossoms.................... 7.00 SEIDCMs. We offer ten varieties. Thers is nothing else as suitable for a rock garden................. 4.50 


\section{GENERAL HORTICULTURAL SUPPLIES}

\section{FERTILIZERS}

ACID PHOSPHATE .......................... $\$ 300$

BONE MEAL. Ground very fine.........100 lbs. 4.50

BLOOD AND BONE. . . . . . . . . . . .

LIME AGRICULTURAI

MURIATE OF POTASH. ............ 100 lbs. $\$ 7.00$

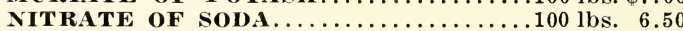

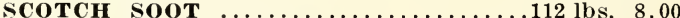

SULPHATE OF AMMONIA ...........100 lbs. 7.50

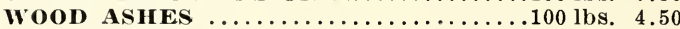

GOAT MANURE. See Inside Back Cover..100 lbs. 4.50

\section{INSECTICIDES}

ANT KILLER. Very effective for use on lawns, golf courses, etc. $4 \frac{1}{2}$ oz. tins $\$ 0.50$.

ARSENATE OF LEAD. (Paste.) Use against caterpillars, and all leaf-chewing insects. $10 \mathrm{lbs}$. $\$ 3.50,25 \mathrm{lbs}$. $\$ 7.00$.

ARSENATE OF LEAD. (Powder.) $10 \mathrm{lbs}$. \$4.00, $25 \mathrm{lbs}$. \$8.00.

BLACK LEAF 40. For sucking insects on all plants. $2 \mathrm{lbs}$. $\$ 3.50,10 \mathrm{lbs} . \$ 14.00$.

BORDEAUX MIXTURE. (Powdered.) For blight, mildew, rust, etc. $10 \mathrm{lbs} . \$ 3.50,25 \mathrm{lbs} . \$ 6.50,100 \mathrm{lbs}$. $\$ 25.00$.

COPPER SOLUTION. For rust on carnations, etc. Gal. $\$ 4.00$.

FISH OIL SOAP. For sucking insects on plants and trees. 5 lbs. $\$ 2.00,25$ lbs. $\$ 8.00$.

LIME SULPHUR POWDER. For dormant spraying. One pound makes from $3 \frac{1}{2}$ to 5 gal. $10 \mathrm{lbs}$. $\$ 3.25,25 \mathrm{lbs}$. $\$ 6.50$.

PARA-DICHLORO-BENZINE. For peach tree borers. $10 \mathrm{lbs}$. $\$ 7.00,25 \mathrm{lbs} . \$ 14.00$.

SCALECIDE. A fine dormant spray. 5 gal. $\$ 7.50,10$ gal. $\$ 12.00$, 30 gal. $\$ 30.00$.

SLCG SHOT. Very effective against potato bugs, rose slugs, currant worms, etc. 5 lbs. $\$ 0.85,10 \mathrm{lbs}$. $\$ 1.50,125 \mathrm{lbs}$. $\$ 14.50$.

X-L-ALL INSECTICIDE. Kills mealy bug, red spider and most insect pests. Gal. $\$ 9.00$.

\section{WEED KILLERS}

DOLGE BRAND. Dilute with 40 parts of water to destroy weeds in roads, gutters and paths. 5 gal. $\$ 2.00,10$ gai. $\$ 16.00,30$ gal. $\$ 40.00$.

\section{CHARCOAL, PEAT AND MOSS}

CHARCOAL. Fine. $100 \mathrm{lbs}$. $\$ 6.50$.

CHA RCOAL. Lump. 100 lbs. $\$ 5.50$.

MOSS, LIVE GREEN SPHAGNUM. Bag $\$ 4.00$.

Moss. Dry. 5-bbl. bale $\$ 5.00$.

MOSS, GREEN. In sheets. Bag $\$ 6.00$

PEAT, FIBRoUs. For orchids, ete. Bag $\$ 4.50$, bale $\$ 30.00$.

PEAT, JERSEY. For mixing with soil. Sack $\$ 3.00$

\section{SPRAYERS}

We can supply any type sprayer at regular market prices, witlout any delay on delivery.

\section{HOES}

Scuffle-English, 5 in............................. $\$ 10$

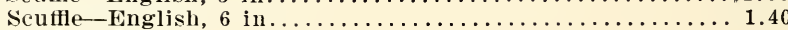
Scutfle_English, 7 in . . . . . . . . . . . . . . . . . . . 1.50 


\section{LABELS}

Wooden, 4 in., painted . . . . . . . . . . . . . . . . . . . . . . $\$ 2.50$

Wooden, 5 in., painted......................... 3.00

Wooden, 6 in., painted........................................ 3.50

Wooden, 8 in., painted..................Per $100 \$ 1.50 \quad 9.00$

Wooden, 10 in., painted....................Per $100 \quad 2.00 \quad 11.00$

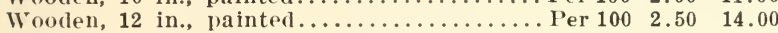

Hanging copper wired, painted, $3 \frac{1}{2}$ in............ 4.00

\section{MATS}

Hotbed, Milo Brand

Each Doz.

Burlay-one side waterproof, $76 \times 78 \ldots \ldots \ldots \ldots \ldots \$ 5.00 \quad \$ 55.00$ Also in continuous lengths up to $100 \mathrm{ft}$, $\$ 0.75$ per lineal $\mathrm{ft}$.

\section{PLANT STAKES}

Peerless

A stake that will last a life time. Ask for $100 \quad 1000$

sample. We recommend it as being

superior to any other stake on the

market. $18 \mathrm{in} . \ldots \ldots \ldots \ldots \ldots \ldots \ldots \ldots \ldots 2.50 \quad \$ 15.00 \quad \$ 120.00$

\section{PLANT STAKES}

Round, green, light.

100

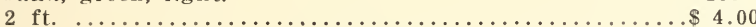

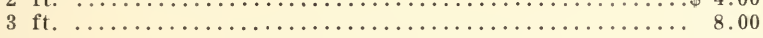

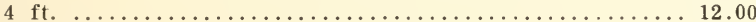

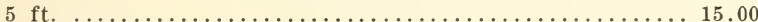

Square, light.

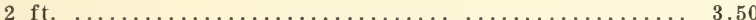

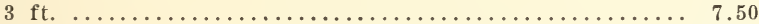

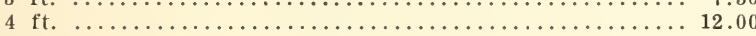

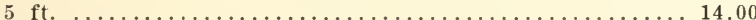

Round, heavy.

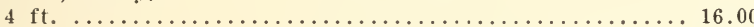

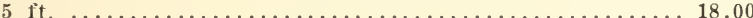

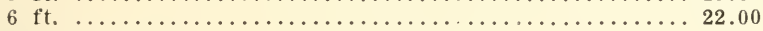

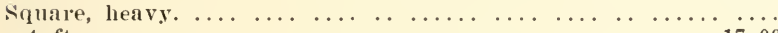

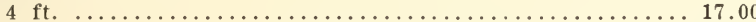

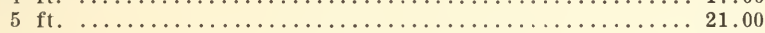

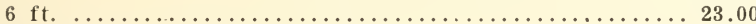

Wire stakes for roses.

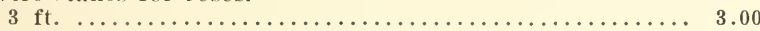

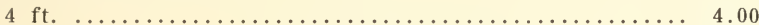

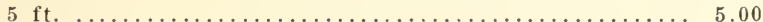

\section{RAFFIA}

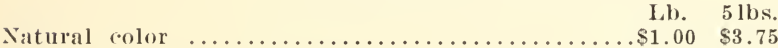

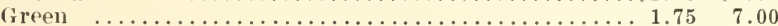

We can secure and ship promptly any sundry not listed in this Catalogue.

\section{PLANTNURSE}

\section{Peatmoss Manure Pot}

Use the Peatmoss Manure Pot-"Plantnurse"-for Young Plants

The Plantnurse Pot does just what its name implies. It nurses aud nourishes the young plants that are entrusted to its care. When put into the soil it absorbs nine times its own weight of moisture, thus releasing the plant nourishing substances which the I'lantnurse Pot contains, thus feeding the voung plant in a most practical and easy manner. It gives the plant strength and protects the young roots. In a few weeks the roots will have grown through the Plantumise Pot and a short time later you will find that the roots and the Plantnurse Pot are one solid ball, ready to plant out without any checking of growth. 


\section{PLANTNURSE POTS-Continued}

The Plantnurse is made from peatmoss and manure and is not only a pot but a manure for the young plant.

It should be used for all Flowering Plants and also for regetables like Tomatoes, Cauliflowers, Cucumbers, Melons, Beans, Lettuce, etc.

Vegetables will be ready for the garden four weeks sooner with the Plantnurse Pot than without it.

Plants raised in Plantnurse Pots can be shipped without danger. The roots are so well protected that they cannot be damaged. The plant will be nourished during shipment.

All pots are packed in cases and bedded in fine granulated peatmoss which assures safe arrival. The peatmoss itself can be used to good advantage.

It can be safely said that wonderful results may be obtained with all kinds of vegetables and flowers by use of the Plantnurse Pot. We recommend a special pot without lime for Azaleas, Rododendrons and Cyclamen.

A special pamphlet will be sent to those interested, along with prices.

\section{INDEX}

Bulbs and Roots..................... 28-29

Dahlias $\ldots \ldots \ldots \ldots \ldots \ldots \ldots \ldots \ldots \ldots \ldots \ldots \ldots \ldots \ldots$

Farm and Field Seeds.................. 26-27

Flower Seed Specialties................ 2-3

Flower Seeds ...................... 13 to 24

Fertilizers $\ldots \ldots \ldots \ldots \ldots \ldots \ldots \ldots \ldots \ldots \ldots \ldots \ldots$

Grass Seeds ..................... 25-26

Gladioli Bulbs .................... 27

Greenhouse Plants ................... 30

Insecticides $\ldots \ldots \ldots \ldots \ldots \ldots \ldots \ldots \ldots \ldots \ldots \ldots \ldots \ldots \ldots \ldots$

Nursery Specialties .................. 4-5

Nursery Stock-General ................ 31

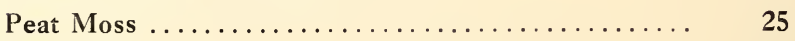

Roses $\ldots \ldots \ldots \ldots \ldots \ldots \ldots \ldots \ldots \ldots \ldots \ldots \ldots \ldots \ldots \ldots \ldots \ldots \ldots \ldots$

Rock Plants $\ldots \ldots \ldots \ldots \ldots \ldots \ldots \ldots \ldots \ldots \ldots \ldots \ldots \ldots \ldots$

Vegetable Seed Specialties............... 3-4

Vegetable Seeds ..................... 6 to 13

Water Lilies ...................... 32-33

Water Plants, Assorted................. 32-33

Garden Sundries ................... 34-36 


\section{SUMMERS GENUINE VENEZUELAN GOAT MANURE}

"The Natural Complete Fertilizer for all Crops"

By chemical analysis, its average composition shows 21/2\% Ammonia, 2\% Phosphoric Acid, available, and $3 \%$ to $4 \%$ Potash, all on a dry basis. But, in addition to this relatively high plant food content, it has, because of its general constituency, an added value as a soil builder.

\section{CONTAINS NO REFUSE}

Venezuelan Goat Manure is free from all refuse, such as straw, weeds and seeds. It is taken into Summers large Baltimore factory, stored in huge piles, for further drying, and later screened, ground and bagged, ready for immediate use.

The plant food is quickly available and because it contains all three elements of Nitrogen, Phosphorous and Potash, it offers an available, balanced plant ration throughout the growing season. It should be applied at the rate of one thousand pounds, to a ton, per acre, depending on the general state of fertility of your land. There is no danger of "Burning" or injury to seed.

We have many testimonials on file from private and commercial growers in the state of Ohio stating the worth of "Summers Venezuelan Goat Manure" and their satisfaction over results gained from its use. We will be glad to give further data on this wonderful Fertilizer.

Price per $100 \mathrm{lb}$. Bags F. O. B. our warehouse $\$ 4.50$. Per ton $\$ 80.00$. Price F. O. B. Baltimore $\$ 70.00$ per ton. 


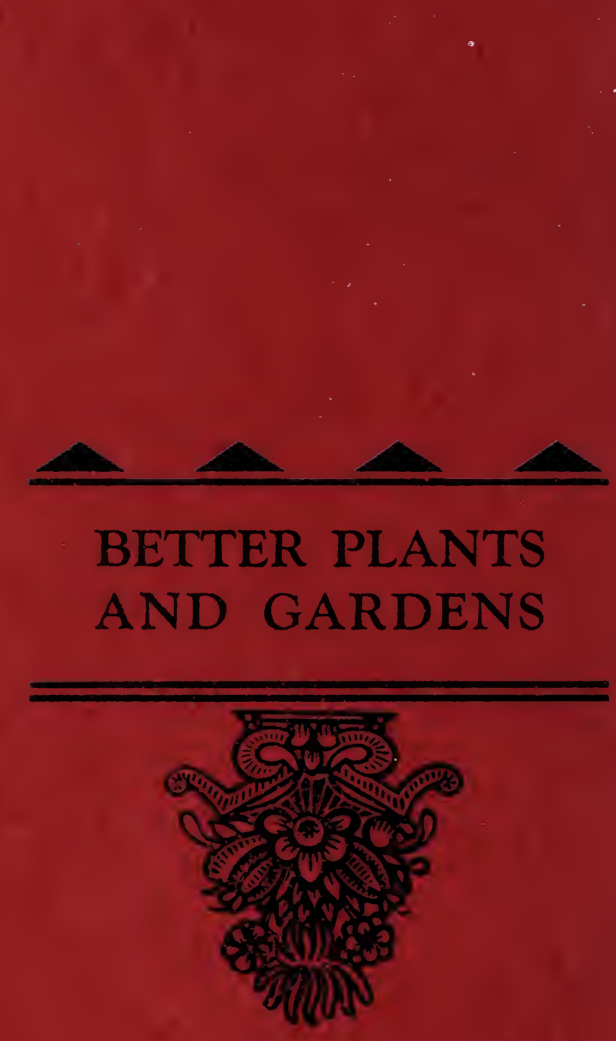

